\title{
NORFACE
}



\section{The impact of immigration on international trade: a meta-analysis}

Murat Genc, Masood Gheasi, Peter Nijkamp and Jacques Poot 


\title{
The impact of immigration on international trade: a meta-analysis*
}

\author{
Murat Genc \\ University of Otago, New Zealand [murat.genc@otago.ac.nz] \\ Masood Gheasi \\ VU University Amsterdam, The Netherlands [m.a.g.gheasi@vu.nl] \\ Peter Nijkamp \\ VU University Amsterdam, The Netherlands [p.nijkamp@vu.nl] \\ Jacques Poot \\ University of Waikato, New Zealand [jpoot@waikato.ac.nz]
}

\begin{abstract}
Since the early 1990s many empirical studies have been conducted on the impact of international migration on international trade, predominantly from the host country perspective. Because most studies have adopted broadly the same specification, namely a log-linear gravity model of export and import flows augmented with the logarithm of the stock of immigrants from specific source countries as an additional explanatory variable, the resulting elasticities are broadly comparable and yield a set of estimates that is well suited to meta-analysis. We therefore compile and analyze in this paper the distribution of immigration elasticities of imports and exports across 48 studies that yielded 300 observations. The results show that immigration complements rather than substitutes for trade flows between host and origin countries. Correcting for heterogeneity and publication bias, an increase in the number of immigrants by 10 percent may be expected to increase the volume of trade on average by about 1.5 percent. However, the impact is lower for trade in homogeneous goods. Over time, the growing stock of immigrants decreases the elasticities. The estimates are affected by the choice of some covariates, the nature of the data (cross-section or panel) and the estimation technique. Elasticities vary between countries in ways that cannot be fully explained by study characteristics; trade restrictions and immigration policies matter for the impact of immigration on trade. The migrant elasticity of imports is larger than that of exports in about half the countries considered, but the publication bias and heterogeneity-corrected elasticity is slightly larger for exports than for imports.
\end{abstract}

Keywords: international trade, imports, exports, immigration, gravity model, meta-analysis

JEL Classification: F16, F22

Version: 18 November 2011

This research is part of the Migrant Diversity and Regional Disparity in Europe (MIDI-REDIE) project, funded by the NORFACE research program Migration in Europe - Social, Economic, Cultural and Policy Dynamics. We are grateful for comments from Roberto Patuelli and from participants at the following meetings: Meta-Analysis of Economic Research (MAER)-Net colloquium, Hendrix College, Conway, Arkansas USA (1-2 October 2010); 57th annual North American meetings of the Regional Science Association International, Denver, Grand Hyatt Hotel (10-13 November 2010); and International Workshop on Immigration and Economic Growth, Amsterdam School of Economics, University of Amsterdam (23-24 June 2011). 


\section{Introduction}

The rapid growth in the foreign-born population in many OECD countries in recent decades has prompted considerable research on the socio-economic impacts of immigration. Among this research activity there have been a number of econometric studies conducted since the 1990s that suggest that immigration has a statistically significant positive impact on merchandise trade, starting with Gould (1994). Such a result is theoretically plausible because of both macro and micro considerations.

At the macro level, it can be argued that immigration-induced population growth increases aggregate demand and output, which - in turn - increases the demand for imports. Exports may increase as well if the presence of immigrants in export industries lowers unit production costs or if immigration enhances the international competitiveness of the host country more broadly (e.g. through greater labor mobility and lower prices). At the micro level, immigrants may be expected to have ongoing links with the home country that can help businesses in the host country to develop networks that can facilitate exporting to, or importing from, the migrant home country. Immigrants also have a good understanding of the institutional and legal arrangements in their home country and, where their native language is different from that of the host country, they can improve communication in trading relationships. Having migrants involved in trade can also enhance the trust in the business relationships between the home and host countries. At the same time, migrants often have a preference for certain goods (particularly, but not exclusively, food items) from the home country. Over time, demand for such goods increases among the host population as well through a 'demonstration effect' (e.g. ethnic restaurants).

The trade facilitation effect of migration applies to both imports and exports, while the 'home preference' effect applies only to imports. The balance of these effects could therefore boost imports more than exports, if the trade facilitation effect would be 'symmetric'. However, if migrants play a key role in expanding exports to their home country, while there are import barriers in the form of tariffs in place in the host country, the impact of immigration on host country exports may exceed that on imports. Most studies to date have focused on developed host nations. ${ }^{1}$ It is clear that, bilaterally, the increase in trade due to immigration applies to the migrant home country as well, whereas the balance of trade effect would be the opposite of that in the host country.

Estimated magnitudes of effects of international migration on trade vary considerably across several applied studies. Because most studies have adopted broadly the same model specification, a log-linear gravity model of export and import flows augmented with the logarithm of the stock of immigrants from specific source countries as an additional explanatory variable, the resulting

\footnotetext{
${ }^{1}$ The study by Caravire Bacarezza and Ehrlich (2006) on Bolivia is a rare exception.
} 
elasticities are broadly comparable and yield a set of estimates that is well suited to meta-analysis. We therefore compile and analyze in this paper the distribution of import and export elasticities of immigration across 48 studies that yielded some 300 estimates. $^{2}$ A smaller meta-analysis of 24 papers, yielding 184 estimates, was published recently (Lin 2011). Besides having a larger sample, the present meta-analysis differs in a number of fundamental ways from Lin (2011). Firstly, we consider imports and exports separately where possible. Secondly, we use 'best-practice' maximum likelihood estimation that accounts for: (i) unobserved heterogeneity; (ii) differences between 'within-study' and 'between-study' variation; and (iii) explicit modeling of publication bias similar to Ashenfelter et al. (1999) and Nijkamp and Poot (2005). ${ }^{3}$ Thirdly, using reported sample means of migration and trade in the primary studies, we convert non-elasticities to elasticities where possible.

Most empirical studies focus on merchandise data and few have explicitly considered trade in services, although some studies have been conducted on the impact of immigration on outbound and inbound tourism (e.g. Law et al. 2009, Gheasi et al. 2011). Others have looked the effect of immigration on Foreign Direct Investment (e.g. Kugler and Rapoport 2007, Javorcik et al. 2010, Driessen et al. 2011). However, in the present paper the focus is predominantly on merchandise trade. Several authors have considered a distinction between differentiated consumer goods and undifferentiated producer goods (such as raw materials). It is plausible that for more 'complex' commodities migrants can play a more important role in trade facilitation. The meta-analysis in fact confirms that the migrant elasticities of trade are less for homogeneous goods.

The next section provides a short narrative review of the salient literature and also motives the use of meta-analysis as an effective means of quantitatively synthesizing this literature. Section 3 describes how the meta-analytic dataset of 300 estimates (also referred to as 'effect sizes') derived from 48 studies has been put together. Section 4 provides a first exploration of the data by means of descriptive statistics. Meta-regression models are discussed in Section 5. Section 6 sums up.

\section{Literature review}

There is a relatively large literature that considers the two-way interaction between international trade and international migration (reviewed in e.g. Poot and Strutt 2010, White 2010, and White and Tadesse 2011). Of the studies that focus on the impact of migration on trade, most suggest that

\footnotetext{
2 This literature continues to expand. We are aware of at least the following papers that became available after the completion of our data set: Parsons (2011), Bowen and Pédussel-Wu (2011), Egger et al. (2011) and Bratti et al. (2011). The findings of these recent papers generally reinforce rather than contradict the present meta-analysis.

${ }^{3}$ Lin (2011)'s meta-regression models were estimated with OLS, with observation weights in some specifications based on the journal ranking and the number of estimates obtained from each study.
} 
migration increases bilateral trade. ${ }^{4}$ The trade facilitation literature makes it clear that the costs of international trade are not only determined by factors such as geographical distance and physical infrastructures, but that there are also other fixed costs, for example the cost of obtaining general skills in trading, specific knowledge of the foreign markets, foreign language ability, trust etc. The employment of immigrants may reduce such costs. Immigrants have a comparative, if not absolute, advantage in gathering and conveying reliable information about foreign markets in which institutional systems (formal and informal), language and culture differ significantly from the host country. Such markets can be the migrant's home country but can also include of course countries that are culturally very similar to the migrant's home country.

While migrants can reduce the cost of international trade by using their knowledge of language, customs, and laws to conduct business with their country of birth or similar countries, they also impact on international trade through the consumption (imports) channel, because immigrants have preferences in favor of the products of their country of birth, and their incomes in the host country give them sufficient purchasing power to afford those goods. Moreover, the presence of foreign-born entrepreneurs may boost the availability of such goods (Bratti et al., 2011). However, migration may also create incentives for domestic firms to produce relevant substitutes (see e.g. Dunlevy and Hutchinson 1999, Girma and Yu 2002).

It should be noted that conventional neoclassical trade theory (like Heckscher-Ohlin) predicts that migration and trade are substitutes but the empirical evidence summarized in this paper suggests that complementarities between migration and trade dominate (see also e.g. Nana and Poot 1996; Gaston and Nelson 2011; Bowen and Pédussel-Wu 2011). In any case, the growth in both trade and migration in recent decades suggests that the traditional theory of trade probably cannot accurately capture the complete relationship between migration and trade (Lewer and Van den Berg, 2009). In practice, the influence of immigration on trade flows has been primarily estimated through the gravity equation. It is therefore important to discuss briefly the gravity model in the next sub-section.

\subsection{The gravity model}

The gravity model of bilateral trade, first introduced by Tinbergen (1962) and Pöyhönen (1963), has withstood the test of time and remains the most popular model to explain international trade patterns. Despite the theory of gravitational forces originating in physics as Newton's law (which states that the gravitational attraction exerted on an object by a body, declines with the (squared) distance between the objects attracted and is proportional to the masses of the bodies), this gravity

\footnotetext{
${ }^{4}$ Of the 48 studies listed in Table 1, 30 report exclusively positive estimates. Among the 18 other studies, only 4 report negative mean estimates.
} 
theory has been long recognized for its consistent empirical success in explaining different types of flows in economics, such as migration, commuting, shopping trips, tourism, and trade. With respect to trade, the model assumes that the amount of trade between two countries is increasing in the economic size of the countries (measured by their national income) and decreasing in the cost of transportation between them (measured by geographical distance). Hence:

$$
F_{i j}=G \frac{E_{i} E_{j}}{D_{i j}^{2}}
$$

in which $F_{i j}$ is the trade (exports, imports, or gross trade) between countries (or regions) $i$ and $j$; $E_{i}$ is the 'economic mass' (e.g. GDP) of $i$; $E_{j}$ is the economic mass of $j$; $D_{i j}$ is the distance between $i$ and $j$; and $G$ is the gravitational constant. According to this equation trade is always positive and balanced. Based on equation (1) the elasticities of trade with respect to $E_{i}$ and $E_{j}$ are identical and equal to 1 , while the elasticity of trade with respect to $D_{i j}$ is -2 . Various regression methods have been proposed to estimate these elasticities (with an OLS regression of a log-linear transformation of (1) being the simplest), combined with some accounting for zero trade flows. ${ }^{5}$ However, these coefficients may not yield in practice precisely the above-stated values. In fact most applications find much smaller elasticities for $E_{i}, E_{j}$ and $D_{i j}$.

The gravity model has a rather high explanatory power, which makes it an attractive specification to test the marginal influence of additional explanatory variables. The popularity of this model increased since some theoretical justifications have been formulated by e.g. Linnemann (1966), Anderson (1979), Bergstrand (1985), Nijkamp and Reggiani (1992), Deardorff (1998) and Helpman et al. (2008).

The influence of immigration on international trade has been estimated primarily through a log-linear gravity model of export and import flows augmented with the logarithm of the stock of immigrants from specific source countries as an additional explanatory variable. Hence we focus in our meta-analysis on studies that are estimating 'gravity-like' equations with migration as an explanatory variable. The standard gravity equation specification for testing the impact of migration on trade between country $i$ and country $j$ is:

$$
\begin{aligned}
& \ln M_{i j}=\alpha_{0}+\alpha_{1} \ln I_{i j}+\alpha_{2} \ln \frac{Y_{i} Y_{j}}{Y_{W}}+\alpha_{3} \ln D_{i j}+\sum_{k=4}^{K} \alpha_{k} \ln Z_{i j}^{k}+\varepsilon_{i j} \\
& \ln X_{j i}=\beta_{0}+\beta_{1} \ln I_{i j}+\beta_{2} \ln \frac{Y_{i} Y_{j}}{Y_{W}}+\beta_{3} \ln D_{i j}+\sum_{k=4}^{K} \beta_{k} \ln Z_{i j}^{k}+\delta_{i j}
\end{aligned}
$$

\footnotetext{
${ }^{5}$ Such as: discarding these observations; adding "1" to the observed volume of trade; treating zero trade as corner solution and use Tobit estimation; using a Heckman-type sample section model; estimating the model in non-linear form by means of Poisson Pseudo-Maximum Likelihood.
} 
where,

$M_{i j}$ is imports into migrant host country $j$, originating from migrant source country $i$

$X_{j i}$ is exports from migrant host country $j$ into migrant source country $i$

$I_{i j}$ is the number of immigrants of country $i$ living in country $j$ (or their share of population)

$D_{i j}$ is a measure of the distance between countries $i$ and $j$

$Z_{i j}^{k}$ represent $k$ other explanatory variables

$\varepsilon_{i j}$ and $\delta_{i j}$ are stochastic error terms; $\alpha_{k}$ and $\beta_{k}$ are the parameters to be estimated $(k=0,1, \ldots, K)$

Recent empirical studies show a variety of amendments of the basic gravity equation, many of which are explicitly considered in the meta-analysis. Such studies have also incorporated other determinants of trade, such as language similarity, colonial ties, access to coastlines, prices or exchange rate, adjacency and trade agreements. Most studies confirm that language, colonial ties, borders and access to coastlines have effects on bilateral trade between countries. Moreover, distance enters the bilateral trade equation in most studies with a negative sign, which is almost always statistically significant, despite the inclusion of a multitude of other dependent variables.

In the present study we are interested in obtaining and understanding the distribution of the estimated $\widehat{\alpha}_{1}$ and $\hat{\beta}_{1}$. We distinguish between import and export elasticities, because for any given host country the impact of immigrants on exports may differ from that on imports. In the literature, the impact on exports is considered more frequently than the impact on imports. From the 48 studies we used for our meta-analysis, we extracted 284 elasticities for exports and 229 elasticities for imports. Before discussing the insights from the meta-analysis, we will first briefly review this approach to the quantitative synthesis of empirical research results.

\subsection{Introduction to meta-analysis}

Meta-analysis is an increasingly popular and valuable tool to offer a statistical synthesis of quantitative studies that address largely the same impact question. One objective of meta-analysis is to test whether the pooling of study results that are individually inconclusive regarding a particular effect, may be able to jointly reject the null hypothesis of no effect (e.g. Stanley, 2001). Alternatively, meta-analysis may provide a stylized average quantity in a popular area of investigation, such as the price elasticity in the demand for gasoline or the rate of convergence of income across regions or countries. More importantly, meta-analysis aims to explain the observed variation in estimates across studies. Meta-analysis was initially applied in the medical and natural sciences to compare and synthesize quantitative impact results. Nowadays, this method is applied in many different 
research fields in economics (see Doucouliagos and Stanley, 2011). For example: Nijkamp and Vindigni (2000) studied agricultural sustainability in several countries; Longhi et al. (2005) studied the impact of immigration on wages; Brander et al. (2007) studied eco-tourism; Cipollina and Salvatici (2010) studied the impact of trade agreements on trade flows; Card et al. (2010) carried out an analysis of evaluations of active labor market policy; and in 2005 the Journal of Economic Surveys devoted a whole special issue (Vol. 19, No.3) to this approach.

Meta-analysis can produce interesting summary results when empirical findings reported in original research publications differ in magnitude and sometimes even in direction. Nonetheless, meta-analysis has also limitations. Clearly, the extraction of results from different studies may not always be an effective substitute for decision makers to carrying out actual case studies specific to their own situation (Holmgren, 2007). Furthermore, the presence of publication bias is often a source of concern. This can arise when results that are not statistically significant or 'contrary to expectation' are less likely to be reported in journals and books, and more likely to be discarded by the researcher. The extent to which the results of papers formally published in books and journals differ from those in unpublished reports, and the extent to which there appear to 'missing' results among all those reported is explicitly considered in the present paper.

While the points made above suggest that scientifically sound meta-analysis of a wide range of empirical research findings on a specific issue in economics is challenging, the number of applications has been growing fast and a set of procedures and software has evolved that have become established practice. ${ }^{6}$ These procedures take into account that in the empirical literature on a particular issue in economics there is unlikely to be homogeneity of effect sizes. The hypothesis that there is a single 'true' effect that underlies every study is unlikely to be correct. Instead there is both observed and unobserved heterogeneity. Observed heterogeneity can be accounted for by running meta-regression models in which study characteristics explain some of the variation in study outcomes. Various meta-regression models have suggested in the literature. We will estimate and compare several such models to gauge the robustness of the main findings.

The most common meta-regression model is a weighted least squares (WLS) approach, with the weights variable being equal to the reciprocal of the estimated variances of the individual effect sizes. If no study characteristics matter and there is no unobserved heterogeneity, a WLS regression is run of the elasticities on a constant term only. The resulting estimated constant term is identical to a simple weighted average of the elasticities and referred to as the Fixed Effect (FE) estimator. ${ }^{7}$ If it is assumed that the observed study characteristics account for all heterogeneity, the FE can be extended by a WLS regression with study characteristics as explanatory variables. However, the FE

\footnotetext{
${ }^{6}$ We use a set of procedures developed in Stata, see Sterne (2009).

${ }^{7}$ This is a different concept from the fixed effects estimator in panel regression models.
} 
estimator assumes absence of unobserved heterogeneity. In the presence of unobserved heterogeneity, the Random Effects (RE) model is a more appropriate choice, because a random effects model considers both between-study and within-study variability and assumes that the studies are a random sample from all possible studies (Sutton et al., 2000). When combining the RE model with the use of a set of deterministic observed study characteristics, a regression model results that can be estimated with the Restrictedl Maximum Likelihood (REML) approach proposed by Harbord and Higgins (2000).

One issue that needs addressing is that most studies yield multiple estimates. The presence of more than one estimate per study can be problematic, because the assumption that multiple estimates obtained from the same study are independent is too strong. Furthermore, counting all estimates equally would tend to give too much weight to studies with many estimates (Stanley, 2001). There are different solutions in the literature to address this problem. Jarrell and Stanley (1990) used dummy variables for each study that provided more than one observation and Disdier and Head (2008) used a panel specification. In our meta-regression estimation, we take account of this issue by using a clustered approach with some estimators, in which each study represents one cluster, irrespective of the number of estimates the study generated. Before applying such procedures to the available estimates of the impact of migration on trade, we first describe in the next section the meta-analytic database.

\section{Data}

In order to acquire a representative set of journal articles, we selected from various economic literature databases all refereed articles that contain an estimation of a gravity model of trade in which immigration has been included as an explanatory variable. While only publications written in the English language were selected, we do not expect this to be a source of bias in the present application. Papers were selected also via extensive search by means of Google Scholar; in this way, we obtained also a large number of downloadable relevant working papers that are not (yet) published in academic journals. We also used the technique of snowballing, viz. carefully scanning through the references of the already included studies. It is noteworthy, that there is a high degree of comparability of results between the published and unpublished papers in our database. As will be shown in the next section, the distributions are very similar although the mean impact of migration on trade is somewhat larger in the unpublished papers than in the refereed journal articles. 
Our final sample consists of 48 papers (31 published in academic journals, 1 in a book, and 16 working papers or unpublished studies). These yielded up to 600 regressions from which the migrant elasticity of exports and/or imports could be derived, half of these representing equation (2) and half representing equation (3). However, some authors focused only on exports while others focused only on imports. Moreover, the studies by Rauch and Trindade (2002) and by Felbermayr et al. (2008), which is an extension of the work by Rauch and Trindade, did not yield estimates that were comparable with those of the other studies, even after converting the reported coefficients into elasticities. ${ }^{8}$ Consequently, the final dataset included 233 elasticities for exports and 178 elasticities for imports. ${ }^{9}$ Table 1 lists the studies, the countries to which the analysis pertains, the number of equations (2) and (3) provided by each study, and whether the data refer to national of sub-national levels of trade.

Almost all studies utilize data from the post 1980 period. The exceptions are Gould (1994) who used US data 1970-1986; Bruder (2004) who used German data 1970-1998, and Dunlevy and Hutchinson (1999) who used historical US data between 1870 and 1980. The difference between elasticities obtained from earlier data and more recent data is tested in the meta-regression models of section 5 .

\section{Table 1 about here}

After the selection of studies has been made, the meta-analyst must decide on what attributes of the studies to record and the form in which such attributes should be coded. Many study characteristics are coded as dummy variables, equal to one for each regression that has a particular attribute. Other study characteristics are numerical, such as the years for which primary study observations were available. The decision which study characteristics to code and how to code these is not straightforward and time consuming. The quality of the meta-analysis dataset is

\footnotetext{
${ }^{8}$ The regression equations estimated by Rauch and Trindade (2002) and Felbermayr et al. (2008) focus on particular migrant groups (predominantly the Chinese), and estimate the impact of the global ethnic network on global bilateral trade. The reported coefficients compare the case of the existing global network with the case of a complete absence of such a network. Most other studies focus on bilateral trade from a host country perspective and provide an elasticity that can be interpreted as the percentage change in trade when the number of immigrants increases by 1 percent from the current mean level.

${ }^{9}$ After considering the entire distribution, four outlier estimates were removed: one each of Grima and Yu (2002), Hong and Santhapparaj (2006), Ghatak and Piperakis (2007) and Lewer and van den Berg (2009).
} 
therefore enhanced by independent verification of the dataset. For the present dataset, the original dataset coded by one of us was independently verified by two co-authors. ${ }^{10}$

To account for the possibility of differences in findings between those published in refereed journal articles, which are subject to some quality control, and those in online working paper series or available through other outlets such as conference papers, the data set includes a dummy variable equal to 1 for published articles. With respect to the econometric methodology employed to estimate the gravity model, a distinction is made between OLS, the Heckman selection model, the Tobit model, the pseudo Poisson model, IV/3SLS/GMM and other methods (such as FGLS).

The dimensions of the panel data (first year, final year, number of cross sections, observations per cross section, number of host countries or regions, number of home countries) are also taken into account. One dummy variable indicates cross-sectional data, while another indicates whether the final data were observed before 2000. It was also noted whether a fixed effects or random effects panel data generating process was assumed, and whether the model was static or allowed for autocorrelation.

Dummy variables also code whether the study estimated both import and export elasticities (there are 163 such pairs of observations); the host country of the migrants; the use of national-level data or sub-national regions; the nature of goods (consumer/differentiated goods; producer/homogeneous goods; all goods); and finally whether the model was estimated for trade with LDCs only.

While the core specification was very similar across most studies, following equations (2) and (3), some covariates did vary between studies. Dummy variables therefore indicate the presence of the following covariates: income per capita; economic scale (GDP or population); distance; geography (adjacency, landlocked, remoteness); cultural similarity, incl. language; trade agreements; migrant skill composition; colonial ties; relative prices or exchange rates; temporary migration or duration of stay. Finally, account was taken of the use of migration as a single independent variable, or whether migration was interacted with other explanatory variables.

All dummy variables and their mean values (i.e. the fraction of observations for which the dummy variable is equal to one) are listed in Table 2 . In the next section, we turn to a descriptive analysis of the available evidence, while the following section reports the meta-regression models.

\section{Table 2 about here}

\footnotetext{
${ }^{10}$ In case of disagreement, a consensus opinion was reached on the final coding. The process of generating the final metaanalytic dataset is very time consuming, requiring several months of selecting and coding papers. The verification process following construction of the initial database took 150 person hours in the present application.
} 


\section{Descriptive results}

The range of estimates that were obtained from the primary studies suggests a great degree of heterogeneity across studies. Table 3 provides the basic descriptive statistics by country. While the vast majority of export and import elasticities are positive, for some countries some negative elasticities have been obtained. The most negative elasticity of exports is obtained for the US (-0.14). The largest positive elasticity can be found among estimates for Australia and the EU, 0.65 in both cases. For imports, the most negative elasticity is again obtained for the US, -0.18 , and the largest positive one for Portugal, 0.56 . The mean elasticity for the effect of immigration on exports is positive for all countries except in the study that uses US/Canada regional trade data (Helliwell, 1997). The largest mean immigration elasticity of exports is 0.43 (Australia). The mean elasticity of imports is also positive for all countries except Greece and Italy, with the largest in magnitude for Portugal namely, 0.35 .

\section{Table 3 about here}

The overall mean of estimated immigration elasticity of exports and imports is the same, 0.17. Of course if estimates existed for all countries, including migrant sending countries, this equality is to be expected as a result of balanced global trade. However, for the sample of countries considered here, it is the result of the countries being about equally divided into those for which the migrant elasticity of imports is greater than that of exports and those for which the opposite is true. Figure 1 shows the quantile plots of the distribution of migration elasticities of exports and imports. Although the mean is about 0.17 for both exports and imports, the mode is somewhat greater for imports $(0.15$ versus 0.12 ). The interquartile range is between 0.06 and 0.28 for exports and between 0.07 and 0.26 for imports. Figure 2 shows that where studies estimated the effects in pairs (163 observations), there is only a slight positive correlation between the effects on imports and exports. The correlation coefficient is 0.44 .

\section{Figure 1 about here}

\section{Figure 2 about here}

The means reported in Table 3 do not take into account the statistical significance of the estimated elasticities. As noted in section 2, weighted averages that incorporate the statistical 
significance of effect sizes (elasticities in this case) in meta-analysis can be calculated in two ways. The first way is the fixed effect (FE) model where it is assumed that there is one 'true' effect size that underlies all the studies and all differences in observed effect sizes (elasticity estimates) are due to sampling errors. The weight assigned to each effect size is then the inverse of its variance (called the within-study variance). The second way is the random effects (RE) model where it is assumed that the true effect size varies from study to study in a stochastic way, and the summary effect is the estimate of the mean of the distribution of effect sizes. The weight assigned to each effect size in this case incorporates both the within-study variance and the between-studies variance. The RE estimate is always closer to the ordinary average than the FE estimate.

Table 4 shows the FE and RE weighted mean effect sizes of the impact of immigration on exports and imports, by country. Besides the differences in model specifications that we will capture in the meta-regression models, the differences in weighted mean effect sizes between countries can also be due to differences across host countries in immigration policies and in restrictions in bilateral trade between pairs of host and home countries. Even across similar countries, the impact can differ. For example, the RE estimate for Australian exports is 0.44 , compared with 0.20 for imports. In New Zealand, immigrants have a higher impact on imports (RE is 0.19 ) than on exports (0.07). Both countries experienced significant trade deficits over the period over which the estimates were calculated. It will be shown by means of the meta-regression models that these differences remain after controlling for differences in study characteristics. Consequently, there are intrinsic differences in these countries trading relations and immigration policies that are likely to have contributed to these differences.

\section{Table 4 about here}

We also observe from Table 4 that the FE elasticity of exports is positive for all countries except for Helliwell (1997) who combines data from Canadian provinces and US states. The largest FE weighted mean elasticity of exports is found for Australia (0.44). The FE elasticity of imports is also positive for all countries except Greece and Italy, with the largest in magnitude for Portugal, 0.42 (FE) or 0.37 (RE). The overall weighted mean of the estimated elasticities of exports is the same as the one for imports with the FE, but the RE weighted mean is slightly lower for imports. As expected, the RE weighted means are much closer to the ordinary averages than the FE weighted means.

The studies also differ by the estimation method used. Table 5 summarizes the mean elasticity estimates obtained by different estimation methods. For exports, 110 out of 233 estimates 
(47.2 percent) are obtained by OLS, and 85 out of 233 (36.5 percent) by the Tobit model. For imports, 84 out of 178 (47.2 percent) of the estimates are obtained by OLS, and 61 out of 178 (34.3 percent) by Tobit. For exports, the ordinary and weighted (FE, RE) estimates obtained by OLS are larger than those obtained with the Tobit method. For imports, the opposite is the case.

\section{Table 5 about here}

The primary studies we identified include both published journal articles and unpublished working and conference papers. Of the 233 effect sizes for exports, 165 (70.8 percent) come from journal articles. For imports, 133 out of 178 (74.7 percent) come from journal articles. The mean elasticities by publication type are provided in Table 6. We observe that the means (weighted or unweighted) do not differ that much by publication type, but the FE estimates are again the smallest. Roughly, all estimated means (unweighted, FE and RE) are between 0.1 and 0.2 , irrespective of whether based on published results or unpublished results. The similarity between results published in journals and in other outlets remains when tested by means of a journal dummy in meta-regression models. This dummy is statistically insignificant. While this suggests that one particular type of publication bias is absent (i.e. journals did not 'select' particular results vis-à-vis other publication outlets), the possibility remains that in all reported estimates statistically significant results are too common, because regressions with small samples and insignificant results remain unreported. In the next section, the latter type of publication bias is addressed by various statistical techniques and shown to be present in this literature.

\section{Table 6 about here}

\section{Meta-regression models}

Meta-regression models are estimated to investigate the extent to which the differences in the results between and within studies can be related to the characteristics of these studies. Let $\hat{\alpha}_{1 i j}$ $\left(\hat{\beta}_{1 i j}\right)$ denote the elasticity for exports (imports) that has been obtained from regression $i$ of study $j$ and $\hat{\sigma}_{\alpha i j}\left(\hat{\sigma}_{\beta i j}\right)$ the reported standard error of the elasticity. If we assume that the underlying effects vary between primary study regressions and denote these effect by $\theta_{\alpha i j}\left(\theta_{\beta i j}\right)$ a randomeffects meta-regression analysis for the export elasticities is the regression model

$$
\hat{\alpha}_{1 i j}=\mathbf{x}_{i j} \gamma_{\alpha}+u_{\alpha i j}+\varepsilon_{\alpha i j}
$$


in which $\theta_{\alpha i j}=\mathbf{x}_{i j} \gamma_{\alpha}, u_{\alpha i j} \sim N\left(0, \tau_{\alpha}^{2}\right)$ and $\varepsilon_{\alpha i j} \sim N\left(0, \sigma_{\alpha i j}^{2}\right)$. Here $\tau_{\alpha}^{2}$ is the between-regressions variance, which is estimated from the data, $\mathbf{x}_{i j}$ is the set of primary regression equation characteristics that are considered to have an impact on the export elasticities, and $\sigma_{\alpha i j}^{2}$ represents the within-regression variance. The standard approach to estimating equation (4) is to estimate the between-regressions variance, $\tau_{\alpha}^{2}$, first, and then the coefficients, $\boldsymbol{\gamma}_{\alpha}$, by weighted least squares by using the weights $1 /\left(\hat{\sigma}_{\alpha i j}^{2}+\hat{\tau}_{\alpha}^{2}\right)$. The algorithm we use to estimate $\tau_{\alpha}^{2}$ is the restricted maximum likelihood (REML) method with the Knapp-Hartung modification (see Harbord and Higgings 2000 for details). However, these results are benchmarked with the FE meta-regression model in which it is assumed that $\tau_{\alpha}^{2}=0$. The latter model can be estimated with WLS with the weights variable equal to $1 /\left(\hat{\sigma}_{\alpha i j}^{2}\right)$ and standard errors of the regression coefficients adjusted for clusters of observations defined by the 48 primary studies. The analysis for imports is analogously based on the regression model

$$
\hat{\beta}_{1 i j}=\mathbf{x}_{i j} \boldsymbol{\gamma}_{\boldsymbol{\beta}}+u_{\beta i j}+\varepsilon_{\beta i j}
$$

The study characteristics we include in $\mathbf{x}_{i j}$ were already listed in Table 2. The results of estimating equations (4) and (5) for the FE regression models are reported in columns (3) and (4) of Table 7 (with standard errors adjusted for clusters of estimates defined by the publications: 44 studies with elasticities for exports and 32 for imports), while those of the RE models are reported in columns (1) and (2) of Table 8. The first two columns of Table 7 provide benchmark OLS regression estimates. The standard errors are generally larger with the REML estimator than with the clustered FE estimator. However, the coefficients are often of a similar magnitude and the two types of model tell qualitatively similar stories.

\section{Table 7 about here \\ Table 8 about here}

Following Ashenfelter et al. (1999), the first variable included in the regressions is the standard error of each estimate. In the absence of publication bias, there should be no correlation between the reported elasticities and their standard errors. ${ }^{11}$ In Table 7, the coefficient of the

\footnotetext{
${ }^{11}$ This idea forms the basis of the Egger test in which the elasticities divided by their standard errors (i.e. the $t$ statistics) are regressed on the reciprocal of the standard errors (also referred to as the precision of the estimates). A statistically
} 
standard error is positive and statistically significant in three of the four columns. ${ }^{12}$ This suggests that there are too many large effect sizes reported for large standard errors, i.e. the small effect sizes are 'missing'. This can also be seen from the so-called funnel plots shown in Figure 3. These are scatter plots of the precision of the estimates (the reciprocals of the standard errors) against the elasticities. In the presence of heterogeneity the funnel plots are only illustrative rather than formal evidence of publication bias, but it is clear that the two scatter plots suggest a bias towards large positive elasticities. Using the Hedges (1992) model, the average effect can be corrected for publication bias, while the extension proposed by Ashenfelter et al. (1999) accounts for heterogeneity. The results of the combined procedure are shown in columns (3) and (4) of Table 8.

\section{Figure 3 about here}

Hedges (1992) formal model of publication bias attempts to estimate the probability that a particular regression is reported. The focus is on the $p$-value that is associated with each elasticity estimate, whereby studies with a lower $p$-value are more likely to be reported. Following this approach, we assume that there is a weight function (based on observed $p$-values) that determines the probability that a study is observed. The weight attached to the probability that the study is observed when $0<p<0.01$, is set equal to one. The relative probabilities that studies are observed with $0.01<p<0.05$, or $p>0.05$ is given by $\omega_{2}$ and $\omega_{3}$ respectively. In the absence of publication bias, $\omega_{2}$ and $\omega_{3}$ should be unity also. In the presence of publication bias, estimates of $\omega_{2}$ and $\omega_{3}$ can be obtained by maximum likelihood, using the likelihood function given in Nijkamp and Poot (2005). The overall pooled average of the elasticities are given by the constants at the bottom of columns (3) and (4) of Table 8. These values are repeated in the left hand column of the lower half of Table 9.

\section{Table 9 about here}

The key parameter estimates of the publication bias correction model without accounting for study characteristics are given at the top of Table 9, those for the models that account for study

\footnotetext{
significant intercept is indicative of publication bias. The $t$ statistic for the intercept is 7.43 for exports $(n=233)$ and 7.97 for imports ( $n=178$ ). In the presence of heterogeneity, this is only suggestive of publication bias, which can then be controlled for by including the standard error in meta-regression models.

${ }^{12}$ This variable has been excluded from the list of study characteristics of Table 8, because columns (3) and (4) of Table 8 report coefficients of the random effects model with publication bias correcting, and columns (1) and (2) reports for comparison the corresponding coefficients without such a correction.
} 
characteristics follow further below. Table 9 shows that, as expected, studies with $p$-values greater than 0.1 are less likely to be reported than studies with highly significant elasticities (the weight is about 0.7 for exports and 0.4 for imports, relative to the $p<0.01$ category). However, for regression estimates of export equations with $p$ values between 0.01 and 0.05 , the model suggests a greater probability of reporting, compared with the benchmark of studies with $p$ values less than 0.01 (about 1.3 versus 1). This is somewhat counterintuitive, but it is a result that was also found by Ashenfelter et al. (1999). In contrast, Nijkamp and Poot (2005) found $1>\widehat{\omega}_{2}>\widehat{\omega}_{3}$ in the wage curve literature. This more intuitively plausible result is here found for imports, with $\widehat{\omega}_{2}$ around 0.6 to 0.7 and $\widehat{\omega}_{3}$ about 0.4 .

The right hand side of Table 9 reports the key parameter estimates of the restricted model that assumes that there is no publication bias, in which case $\omega_{2}=\omega_{3}=1$. Minus twice the difference in the log likelihood is Chi-square (2) distributed. The critical value is 9.21 at the 1 percent level and 5.99 at the 5 percent level. The test statistics for exports are 4.52 (without study characteristics) and 5.06 (with study characteristics). Hence in both cases, publication bias is formally rejected. For imports, the test values are 12.78 and 11.4 respectively, hence providing evidence of publication bias at the 1 percent level.

The RE estimates that were already reported in Tables 4, 5 and 6 are again included in Table 9 under the column "Restricted", in the upper half of the table (not accounting for study characteristics). The values are 0.168 and 0.164 for exports and imports respectively. The pooled average RE effects in the REML model (the reported constants in columns (1) and (2) of Table 8) are identical to those reported on the right hand side of the lower panel of Table 9).

Without accounting for study characteristics, the 'between-regression' heterogeneity is huge: compare the RE estimate for exports in Table 9 (publication bias assumed) of 0.162 with the standard deviation of stochastic heterogeneity $\hat{\tau}_{\alpha}=0.143$. For imports the values are 0.136 and 0.126 respectively. Accounting for study characteristics, the RE estimates increase slightly (from 0.162 to 0.164 for exports, and from 0.136 to 0.150 for imports) but the 'residual' heterogeneity is reduced considerably (to 0.088 and 0.081 respectively). We also see from the lower half of Table 9 that accounting for publication bias lowers the RE estimate for exports by about 0.004 and for imports by about 0.018 . In summary, based on the available studies, the 'best' estimate of the immigration elasticity of exports is about 0.16 and of imports about 0.15 . In the remainder of this section we consider how these estimates are influenced by study characteristics, based on the 
reported regression coefficients in Tables 7 and 8. Each variable enters these regressions in deviations from the mean, so that the constant terms are equal to the pooled average effects. ${ }^{13}$

In economic phenomena where the causality can run in both directions, regressions with cross-sectional data usually exaggerate the causal relationship (because such models cannot account for unmeasured phenomena that lead to a 'sorting' of the cross-sectional units). In the present application, there is some evidence of larger elasticities with cross-sectional data, with cross often being positive but the effect is not statistically significant for exports.

Another issue is the choice of period over which models are estimated. The variable before2000 is generally positive and statistically significant in columns (3) and (4) of Table 7, and all columns but column (2) of Table 8 . This suggests that the trade-inducing effect of immigrants is particularly strong when the first migrants from a particular origin arrive, but that the impact becomes smaller once a sizeable migrant community has been established. This is consistent with the recent evidence provided by Egger et al. (2011) who suggest that the effect might be declining to zero for immigrant stocks greater than 4000 .

The next set of study characteristics in Tables 7 and 8 captures the heterogeneity due to variation in estimation method with OLS being the reference category. We see that estimation methods matter in some cases, but there is little consistency with respect to statistically significant effects. The tobit elasticities are possibly greater than those from OLS (but not significantly for imports). For example, the censored Least Absolute Deviation estimator of the tobit model in Herander and Saavedra (2005) yielded larger elasticities.

Almost all of the coefficients on country dummy variables are statistically significant for export elasticities. For import elasticities there are more statistically insignificant coefficients but some still indicate that the effect sizes vary with the host country. The reference category is the study by Lewer and van den Berg (2009) who pool data from 16 OECD countries and a large set of immigrant source countries. We conclude that, even after controlling for other factors, there are inter-country differences in the immigrant elasticities of imports and exports. This is plausible given relatively large differences between countries in immigration and trade policies. However, the cause of such differences goes beyond what can be explained by the observable study characteristics. The use of country data rather than regional (state) data does not have a statistically significant impact on the results.

Table 7 suggests that the trade facilitation effect of immigrants is less for homogeneous / producer goods. These are goods for which there is unlikely to be a home bias effect. The resulting

\footnotetext{
${ }^{13}$ The constant in Table 7 is the pooled ordinary mean in columns (1) and (2); and the fixed effects mean in columns (3) and (4). In Table 8, the constant is the random effects mean in columns (1) and (2) and the publication bias corrected random effects mean in columns (3) and (4).
} 
drop in the elasticity ranges from about 0.06 to 0.12 . For differentiated goods there is no statistically significant difference compared with the reference category of all goods.

There is no convincing evidence that the impact of immigrants on trade is greater for trade with developing countries than for trade with countries generally. The coefficient on Idctrade is only statistically significant for exports in column (1) of Table 7. We find that panel models that include the lagged volume of trade in their specification find a smaller impact of immigration, particularly for imports (except for the FE model of columns (3) and (4) of Table 7). This result is highly plausible because the coefficient of immigration in dynamic models is the short-run effect, which is smaller than the long-run effect.

Interacting migration with other explanatory variables appears to have no effect in the gravity model. There is some evidence that inclusion of the income per capita variable in the gravity model increases the estimated impact of immigration on imports. A distance variable does the same thing for exports. The use of a country 'scale' variable has no effect on the immigrant elasticities. The use of variables that account for geography (such as whether countries are landlocked or remote) removes some of the effect of migration on trade. The effect of variables measuring culture or language does not have an impact on the migration elasticities of trade. The use of a trade agreements variable reduces the immigrant elasticity of imports but not significantly of exports. The effects of accounting for migrant skills or colonial ties are negligible.

Interestingly, the use of an exchange rate or price ratio variable in the regression equation lowers the migrant elasticity of exports, but increases it of imports. Finally, accounting for migrants' duration of residence or home country fixed effects has no generally conclusive effect.

Finally, the models discussed so far consider the estimation of the immigration elasticity of exports independently from the estimation for imports. Since many papers estimated both effects, the question arises whether joint estimation can improve the efficiency of the estimates. A total of 163 pairs of estimates are available. However, Figure 2 clearly shows that the correlation between the elasticity for imports and for exports is actually quite low. To consider the matter formally, we re-estimated columns (1) and (2) of Table 7 with the Seemingly Unrelated Regression (SUR) model. This yielded results that are qualitatively similar to those already reported. Specifically: the presence of publication bias among elasticities for imports (but not significantly for exports); the elasticities estimated with data before 2000 are larger; the significance of some country and method effects; the elasticities for homogeneous goods and those of (short-run) elasticities in dynamic models are significantly smaller. ${ }^{14}$

\footnotetext{
${ }^{14}$ To save space, these results are not included in the tables. They are available upon request from the authors.
} 


\section{Conclusions}

In this paper we analyzed the distribution of immigration elasticities of imports and exports across 48 studies that yielded 300 estimates. The results confirm that immigration boosts trade, but the impact is less on trade in homogeneous goods. An increase in the number of immigrants by 10 percent increases the volume of trade by about 1.5 percent. Among the countries considered, the effect on imports is greater than that on exports in about half of the countries, but after correcting for unobserved heterogeneity and publication bias, the average immigrant elasticity of exports is slightly larger than that of imports. The estimates are affected by the choice of some covariates, the nature of the data (cross-section or panel) and the estimation technique. Elasticities vary between countries in ways that cannot be explained by study characteristics; host country differences in immigration and trade policies may matter for the impact. The positive elasticities of immigrants for both exports and imports indicate that the stock of migrants in the host country complements trade flows.

As in many areas of applied economic research, the question remains to what extent the estimated partial correlation is indicative of a truly causal effect. The meta-regression models compared estimates obtained with methods that accounted for endogeneity (such as IV, 3SLS and GMM) with those that did not, but the results did not conclusively show a bias of the latter. However, the selected instruments may not be effective in reducing reverse causality in any case. Current migration is commonly instrumented by past migrant stocks under the assumption that migration flows are based on historical networks and 'well-trodden paths' rather than current economic conditions. This does nonetheless not preclude a strong link between past migration and current trade that violates the assumption of independence between the instrument and the error term in the trade equation. Consequently, alternative methods should be considered, such as generalized propensity score estimation or the use of 'natural experiments', which have already been extensively applied to the issue of the labor market impact of immigration (see Longhi et al. 2010). For the analysis of micro level evidence, e.g. whether the act of migration is an inducement to engage in international trade, one might even consider the impact of 'true' randomization where migrants are selected through ballots (e.g. Gibson et al. 2011).

Other possibilities for further research would include a focus on developing countries. The impact of the diaspora has been to date predominantly assessed with respect to the host country rather than the source country. ${ }^{15}$ The meta-analysis suggests that bilateral trade impact of immigration may on average slightly favor the host country (with the elasticity for exports being

\footnotetext{
${ }^{15}$ Blanes-Cristobal (2010) provides a recent contribution on the link between immigration and trade for developing countries.
} 
slightly larger than for imports). Of course, a negative impact on the trade balance of the sending country might be offset by significant remittances. Additionally, there could be impacts on services trade (including tourism) and foreign direct investment. Clearly, the consideration of the impact of international migration on both sending and receiving countries with respect to the full range of international economic linkages, and their interactions, offers still much scope for further research.

\section{References}

Anderson, J. E. (1979) A theoretical foundation for the gravity equation. American Economic Review 69: 106-116.

Ashenfelter, O., Harmon, C. and Oosterbeek, H. (1999) A review of estimates of the schooling/earnings relationship, with tests for publication bias. Labour Economics 6: 453-470.

Bandyopadhyay, S., Coughlin, C.C., and Wall, H.J. (2008) Ethnic networks and US exports. Review of International Economics 16: 199-213.

Bardhan, A.D., and Guhathakurta, S. (2004) Global linkages of sub-national regions: coastal exports and international networks. Contemporary Economic Policy 22: 225-236.

Bergstrand, J.H. (1985) The gravity equation in international trade: some microeconomic foundations and empirical evidence. Review of Economics and Statistics 76: 474-481.

Blanes, J. V. (2006) Immigrant's characteristics and their different effects on bilateral trade: evidence from Spain. Department of Economics Working Paper 08/06. Sevilla: University of Pablo de Olavide.

Blanes-Cristóbal, J. V. (2008) Characteristics of immigrants and bilateral trade. Revista de Economía Aplicada 48: 133-159.

Blanes-Cristóbal, J. V. (2010) The link between immigration and trade in developing countries. Working papers on International Economics and Finance DEFI 10-07, Spanish Association of International Economics Finance, www.aeefi.com

Bowen, H.P. and Pédussel-Wu, J.P. (2011) Immigrant specificity and the relationship between trade and immigration: theory and evidence. McColl School of Business DP 2011-01. Charlotte NC: Queens University of Charlotte.

Brander, L.M., van Beukering, P., and Cesar, H.S.J. (2007) The recreational value of coral reefs: a meta-analysis. Ecological Economics 63: 209-218.

Bratti, M., De Benedictis, L., and Santoni, G. (2011) On the pro-trade effects of immigrants. http://works.bepress.com/luca_de_benedictis/21

Bruder, J. (2004) Are trade and migration substitutes or complements? The case of Germany, 19701998. Mimeo. Rostock: Department of Economics, University of Rostock.

Bryant, J., Genc, M., Law, D.R.C. (2004) Trade and migration to New Zealand. New Zealand Treasury Working Paper 04/18. Wellington: New Zealand Treasury.

Caravire Bacarreza, G.J., and Ehrlich, L. (2006) The impact of migration on foreign trade: a developing country approach. Latin American Journal of Economic Development 6: 125-146.

Card, D., Kluve, J. and Weber, A. (2010) Active Labour Market Policy Evaluations: A Meta-Analysis. Economic Journal 120: F452-477.

Ching, H.S., and Chen, L.L. (2000) Links between emigrants and the home country: the case of trade between Taiwan and Canada. In: H. Kohno., P. Nijkamp., and J. Poot (eds) Regional Cohesion and Competition in the Age of Globalization. Cheltenham: Edward Elgar.

Cipollina, M., and Salvatici, L. (2010) Reciprocal trade agreements in gravity models: a meta-analysis. Review of International Economics 18: 63-80.

Co, C.Y., Euzent, P., and Martin, T. (2004) The export effect of immigration into the US. Applied Economics 36: 573-583. 
Coughlin, C.C., and Wall, H. J. (2010) Ethnic networks and trade: intensive vs. extensive margins. Federal Reserve Bank of St. Louis Working Papers No. 16. St. Louis: Federal Reserve Bank of St. Louis.

Deardorff, A. (1998) Determinants of bilateral trade: does gravity work in a classical world? In J.A. Frankel (ed.) Regionalization of the World Economy, 7-28. Chicago: University of Chicago Press.

Disdier, A.C., and Head, K. (2004) The puzzling persistence of the distance effect on bilateral trade.

Doucouliagos, C. and Stanley, T.D. (2011) Are all economic facts greatly exaggerated? Theory competition and selectivity. Journal of Economic Surveys doi 10.1111/j.1467-6419.2011.00706.x

Dunlevy, J.A. (2006) The influence of corruption and language on the protrade effect of immigrants: evidence from the American states. Review of Economics and Statistics 88: 182-186.

Dunlevy, J.A., and Hutchinson, W.K. (1999) The impact of immigration on American import trade in the late nineteenth and early twentieth centuries. Journal of Economic History 59: 1043-1062.

Egger, P.H., von Ehrlich, M. And Nelson, D.R. (2011) Migration and trade. CESifo Working Paper 3467. www.cesifo.org

Faustino, H. C. and Leitão, N.C. (2008a) Using the gravity equation to explain the Portuguese immigration-trade link. Technical University of Lisbon School of Economics and Management Working Paper No 08/12. Lisbon: Technical University of Lisbon.

Faustino, H. C. and Leitão, N.C. (2008b) Immigration and trade in Portugal: a static and dynamic panel data analysis. Technical University of Lisbon School of Economics and Management Working Paper No 08/31. Lisbon: Technical University of Lisbon.

Faustino, H. C., and Peixoto, J. (2009) Immigration-trade links: the impact of recent immigration on Portuguese trade. Technical University of Lisbon School of Economics and Management Working Paper No 09/36. Lisbon: Technical University of Lisbon.

Felbermayr, G.J., Jung, B., and Toubal, F. (2008) Ethnic networks, information, and international trade: revisiting the evidence. University of Hohenheim Institute für Volkswirtschaftslehre Discussion Papper No. 306. Stuttgart: University of Hohenheim.

Ghatak, S., and Piperakis, A.S. (2007) The impact of Eastern European immigration to UK trade. Kingston University Economic Discussion Paper No. 2007-03. London: Kingston University.

Ghatak, S., Pop-Silaghi, M.I., and Daly, V. (2009) Trade and migration flows between some CEE countries and the UK. Journal of International Trade \& Economic Development 18: 61-78.

Driessen, I., Gheasi, M., Nijkamp, P., and Rietveld, P. (2011) Migrants and international economic linkages: a meta-overview. TI Discussion Paper 11-147/3. Amsterdam and Rotterdam: Tinbergen Institute.

Gaston, N. and Nelson, D.R. (2011) Bridging trade theory and labour econometrics: the effects of international migration. Journal of Economic Surveys doi: 10.1111/j.1467-6419.2011.00696.x

Gheasi, M., Nijkamp, P., and Rietveld, P. (2011) Migration and tourist flows. In: A. Matices., P. Nijkamp., and M. Sarmento (eds) Advances in Tourism Economics: Impact Analysis. Berlin: Springer Verlag (forthcoming).

Gibson, J., McKenzie, D. and Stillman, S. (2011) The impacts of international migration on remaining household members: omnibus results from a migration lottery program. Review of Economics and Statistics 93: 1297-1318.

Girma, S., and Yu, Z. (2002) The link between immigration and trade: evidence from the United Kingdom. Review of World Economics 138: 115-130.

Gonçalves, N., and Africano, A.P. (2009) The immigration and trade link in the European union integration process. Universidade do Porto, Faculdade de Economia do Porto Working Papers No 11. Porto: University of Porto.

Gould, D.M. (1994) Immigrant links to home country: empirical implications for U.S. bilateral trade flows. Review of Economics and Statistics 76: 302-316.

Harbord, R.M. and Higgins, J.P.T. (2000) Meta-regression in Stata. Stata Journal 8: 493-519.

Hatzigeorgiou, A. (2010) Migration as trade facilitation: assessing the links between international trade and migration. The B.E. Journal of Economic Analysis \& Policy 10: 1-33. 
Head, K., and Ries, J. (1998) Immigration and trade creation: econometric evidence from Canada. Canadian Journal of Economics 31: 47-62.

Hedges, L.V. (1992) Modeling publication selection effects in meta-analysis. Statistical Science 7: 246-255.

Helliwell, J.F. (1997) National borders, trade and migration. Pacific Economic Review 3: 165-185.

Herander, M.G., and Saavedra, L.A. (2005) Exports and the structure of immigrant-based networks: the role of geographic proximity. Review of Economics and Statistics 87: 323-335.

Holmgren, J. (2007) Meta-analysis of public transport demand. Transportation Research Part A: Policy and Practice 41: 1021-1035.

Hong, T.C., and Santhapparaj, A.S. (2006) Skilled labor immigration and external trade in Malaysia: a pooled data analysis. Perspectives on Global Development and Technology 5: 351- 366.

Ivanov, A.V. (2008) Information effects of migration on trade. University of Mannheim Center for Doctoral Studies in Economics No 42. Mannheim: University of Mannheim.

Jansen, M., and Piermartini, R. (2005) The impact of mode 4 liberalization on bilateral trade flows. CEPR Discussion paper No. 5382. London: Centre for Economic Policy Research.

Jansen, M., and Piermartini, R. (2009) Temporary migration and bilateral trade flows. The World Economy 32: 735-753.

Jarrell, S.B., and Stanley, T.D. (1990) A meta-analysis of the union wage gap. Industrial and Labor Relations Review 44: 54-67.

Javorcik, B.S., Özden, Ç, Spatareanu, M. and Neagu, C. (2010) Migrant networks and foreign direct investment, Journal of Development Economics, Article in Press.

Kugler, M. and Rapoport, H. (2007) International labor and capital flows: complements or substitutes? Economics Letters 94: 155-162.

Law, D., Genc, M., and Bryant, J. (2009) Trade, diaspora and migration to New Zealand. NZ Institute for Economic Research Working Papers No.2009/4. Wellington: New Zealand Institute for Economic Research.

Lewer, J. J., and van den Berg, H. (2009) Does immigration stimulate international trade? Measuring the channels of influence. The International Trade Journal. 23: 187-230.

Lin, F. (2011) The pro-trade impacts of immigrants: a meta-analysis of network effects. Journal of Chinese Economic and Foreign Trade Studies 4(1): 17-27.

Linnemann, H. (1966) An Econometric Study of International Trade Flows. Amsterdam: North Holland.

Longhi, S., Nijkamp, P., and Poot, J. (2005) A meta-analytical assessment of the effect of immigration on wages. Journal of Economic Surveys 19: 451-477.

Longhi, S., Nijkamp, P. and Poot, J. (2010) Joint Impacts of Immigration on Wages and Employment: Review and Meta-analysis. Journal of Geographical Systems 12: 355-387.

Murat, M., and Pistoresi, B. (2009) Migrant networks: empirical implications for the Italian bilateral trade. International Economic Journal 23: 371-390.

Nana, G. and Poot, J. (1996) A Study of Trade Liberalisation and Factor Mobility with a CGE Model of Australia and New Zealand. Studies in Regional Science 26: 27-52.

Nijkamp, P. and Poot, J. (2005) The Last Word on the Wage Curve? Journal of Economic Surveys 19(3): 421-450.

Nijkamp, P., and Vindigni, G. (2000) Food security and agricultural sustainability: a comparative multi-country assessment of critical success factors. Tinbergen Institute Discussion papers 70/3. Amsterdam: Tinbergen Institute.

Nijkamp, P. and Reggiani, A. (1992) Interaction, Evolution and Chaos in Space. Berlin: Springer.

Parsons, C. (2005) Quantifying the trade-migration nexus of the enlarged EU. Sussex Migration Working Paper No.27. Falmer: University of Sussex.

Parsons, C. (2011) Do migrants really foster trade? The trade-migration nexus, a panel approach 1960-2000. Research Paper 2011/10. The Leverhulme Centre for Research on Globalisation and Economic Policy, University of Nottingham. 
Partridge, J., and Furtan, H. (2008) Immigration wave effects on Canada's trade flows. Journal of Canadian Public Policy 34: 193-214.

Peri, G., and Requena, F. (2009) The trade creation effect of immigrants: evidence from the remarkable case of Spain. NBER Working Paper No 15625. Cambridge, Mass.: National Bureau of Economic Research.

Piperakis, A.S., Milner, C., and Wright, P.W. (2003) Immigration, trade costs and trade: gravity evidence for Greece. Journal of Economic Integration 18: 1-13.

Poot, J. and Strutt, A. (2010) International Trade Agreements and International Migration. The World Economy, 33(12): 1923-1954.

Pöyhönen, P. (1963) A tentative model for the volume of trade between countries. Weltwirtschaftliches Archiv 90: 93-99.

Qian, M. (2008) The economic relationship between trade and immigration in New Zealand. Integration of Immigrants Programme Working Papers No 1. Albany: Massey University.

Rauch, J.E., and Trindade, V. (2002) Ethnic Chinese networks in international trade. Review of Economics and Statistics 84: 116-130.

Stanley, T.D. (2001) Wheat from Chaff: meta-analysis as quantitative literature review. Journal of Economic Perspectives 15: 131 -150.

Sterne, J.A.C. (2009) Meta-Analysis in Stata; An Updated Collection from the Stata Journal. College Station Texas: Stata Press.

Sutton, A.J., Abrams, K.R., Jones, D.R., Sheldon, T.A., and Song, F. (2000) Methods for Meta-Analysis in Medical Research. Chichester: John Wiley.

Tadesse, B., and White, R. (2008) Do immigrants counter the effect of cultural distance on trade? Evidence from US state-level exports. Journal of Socio-Economics 37: 2304-2318.

Tadesse, B., and White, R. (2010) Cultural distance as a determinant of bilateral trade: do immigrants counter the effect of cultural differences? Applied Economics Letters 17: 147-152.

Tinbergen, J. (1962) Shaping the World Economy: Suggestions for an International Economic Policy. New York: The Twentieth Century Fund.

Wagner, D., Head, K., and Ries, J. (2002) Immigration and the trade of provinces. Scottish Journal of Political Economy 49: 507-525.

White, R. (2007a) An examination of the Danish immigrant-trade link. International Migration 45: 6186.

White, R. (2007b) Immigrant trade links, transplanted home bias and network effects. Applied Economics 39: 839-852.

White, R. (2009a) Immigration, trade and home country development: state-level variation in the US immigrant-export link. Journal of International Migration and Integration 10: 121-143.

White, R. (2009b) Immigration, trade and product differentiation. Economic Issues 14: 43-64.

White, R. (2010) Migration and International Trade: The US Experience Since 1945. Cheltenham UK and Northhampton MA USA: Edward Elgar.

White, R., and Tadesse, B. (2007a) East-West migration and the immigrant-trade link: evidence from Italy. The Romanian Journal of European Studies 5-6: 67- 84.

White, R., and Tadesse, B. (2007b) Immigration policy, cultural pluralism and trade: evidence from the white Australia policy. Pacific Economic Review 12: 489-509.

White, R., and Tadesse, B. (2008) Immigrants, cultural distance and U.S state-level exports of cultural products. North American Journal of Economics and Finance 19: 331-348.

White, R. and Tadesse, B. (2011) International Migration and Economic Integration. Cheltenham UK and Northhampton MA USA: Edward Elgar. 
Table 1: The papers used in the meta-analysis

\begin{tabular}{|c|c|c|c|c|c|}
\hline Study & Time period & Country & Level & $\begin{array}{l}\text { \# estim. } \\
\text { elast. } \\
\text { exports }\end{array}$ & $\begin{array}{l}\text { \# estim. } \\
\text { elast. } \\
\text { imports }\end{array}$ \\
\hline Gould (1994) & $1970-1986$ & US & National & 3 & 3 \\
\hline Helliwell (1997) & $1990-1990$ & US/Canada & Sub-national & 2 & 2 \\
\hline Head and Ries (1998) & $1980-1992$ & Canada & National & 4 & 4 \\
\hline Dunlevy and Hutchinson (1999) & $1870-1910$ & US & National & 0 & 6 \\
\hline Ching and Chen (2000) & $1980-1995$ & Canada & Sub-national & 1 & 1 \\
\hline Girma and Yu (2002) & 1981-1993 & UK & National & 10 & 6 \\
\hline Rauch and Trindade (2002) & $1980-1980$ & World & National & 12 & 12 \\
\hline Wagner, Head and Ries (2002) & $1992-1995$ & Canada & Sub-national & 3 & 3 \\
\hline Piperakis, Milner and Wright (2003) & $1981-1991$ & Greece & National & 2 & 2 \\
\hline Bardhan and Guhatkakurta (2004) & 1994-1996 & US & Sub-national & 4 & 0 \\
\hline Bruder (2004) & $1970-1998$ & Germany & National & 1 & 1 \\
\hline Bryant et al. (2004) & $1981-2001$ & New Zealand & National & 5 & 5 \\
\hline Co et al. (2004) & $1993-1993$ & US & Sub-national & 6 & 0 \\
\hline Herander and Saavedra (2005) & $1993-1996$ & US & Sub-national & 8 & 0 \\
\hline Jansen and Piermartini (2005) & $2000-2002$ & US & National & 14 & 14 \\
\hline Parsons (2005) & $1994-2001$ & EU & National & 2 & 2 \\
\hline Blanes (2006) & $1995-2003$ & Spain & National & 18 & 18 \\
\hline Caravire Bacarreza and Ehrlich(2006) & $1990-2003$ & Bolivia & National & 1 & 1 \\
\hline Dunlevy (2006) & $1990-1992$ & US & Sub-national & 5 & 0 \\
\hline Hong and Santhapparaj (2006) & $1998-2004$ & Malaysia & National & 6 & 6 \\
\hline Ghatak and Piperakis (2007) & $1991-2001$ & UK & National & 4 & 4 \\
\hline White (2007-a) & $1980-2000$ & Denmark & National & 28 & 28 \\
\hline White (2007-b) & $1980-2001$ & US & National & 3 & 3 \\
\hline White and Tadesse (2007-a) & $1996-2001$ & Italy & National & 1 & 1 \\
\hline White and Tadesse $(2007-b)$ & $1989-2000$ & Australia & National & 15 & 15 \\
\hline Bandyopadyay et al. (2008) & $1990-2000$ & US & Sub-national & 2 & 0 \\
\hline Blanes-Cristóbal (2008) & $1995-2003$ & Spain & National & 5 & 5 \\
\hline Faustino and Leitao (2008- a) & $1995-2003$ & Portugal & National & 1 & 1 \\
\hline Faustino and Leitao (2008- b) & $1995-2003$ & Portugal & National & 1 & 1 \\
\hline Felbermayr et al. (2008) & $1980-1980$ & World & National & 36 & 36 \\
\hline Ivanov (2008) & $1996-1998$ & Germany & National & 4 & 0 \\
\hline Partridge and Furtan (2008) & $2003-2004$ & Canada & Sub-national & 2 & 2 \\
\hline Qian (2008) & $1980-2005$ & New Zealand & National & 8 & 8 \\
\hline Tadesse and White (2008) & $2000-2000$ & US & Sub-national & 6 & 0 \\
\hline White and Tadesse (2008) & $2000-2000$ & US & Sub-national & 8 & 0 \\
\hline Faustino and Peixoto (2009) & $1995-2006$ & Portugal & National & 1 & 1 \\
\hline Ghatak, Silaghi and Daly (2009) & $1996-2003$ & UK & National & 2 & 2 \\
\hline Gonçalves and Africano (2009) & $1995-2007$ & EU & National & 6 & 0 \\
\hline Jansen and Piermartini (2009) & $1996-2004$ & US & National & 14 & 14 \\
\hline Law et al. (2009) & $1981-2006$ & New Zealand & National & 2 & 2 \\
\hline Lewer and van den Berg (2009) & $1991-2000$ & World & National & 2 & 1 \\
\hline Murat and Pistoresi (2009) & $1990-2005$ & Italy & National & 1 & 1 \\
\hline Peri and Requena (2009) & $1995-2008$ & Spain & Sub-national & 9 & 0 \\
\hline White (2009a) & $1993-1993$ & US & Sub-national & 3 & 0 \\
\hline White (2009b) & $1980-1997$ & US & National & 24 & 24 \\
\hline Coughlin and Wall (2010) & $1990-2000$ & US & Sub-national & 4 & 0 \\
\hline Hatzigeorgiou (2010) & $2007-2007$ & World & National & 0 & 9 \\
\hline Tadesse and White (2010) & $2000-2000$ & US & Sub-national & 6 & 0 \\
\hline
\end{tabular}


Table 2: Definition of dummy variable study characteristics and mean values ( $n=248$ )

\begin{tabular}{|c|c|c|}
\hline cross & Equals 1 if the estimate was obtained with cross-sectional data & 0.3508 \\
\hline before2000 & Equals 1 if the elasticity is obtained with data from years before 2000 & 0.3427 \\
\hline heckman & Equals 1 if the estimation method is Heckman & 0.0403 \\
\hline iv & Equals 1 if the estimation method is IV/3SLS/GMM/FGLS & 0.0806 \\
\hline ols & Equals 1 if the estimation method is OLS & 0.4919 \\
\hline other & Equals 1 if some other estimation method is used & 0.0282 \\
\hline poisson & Equals 1 if the estimation method is pseudo poisson & 0.0161 \\
\hline tobit & Equals 1 if the estimation method is tobit & 0.3427 \\
\hline australia & Equals 1 if the host country is Australia & 0.0605 \\
\hline bolivia & Equals 1 if the host country is Bolivia & 0.0040 \\
\hline canada & Equals 1 if the host country is Canada & 0.0403 \\
\hline denmark & Equals 1 if the host country is Denmark & 0.1129 \\
\hline$e u$ & Equals 1 if the host region is the European Union & 0.0323 \\
\hline germany & Equals 1 if the host country is Germany & 0.0202 \\
\hline greece & Equals 1 if the host country is Greece & 0.0081 \\
\hline italy & Equals 1 if the host country is Italy & 0.0081 \\
\hline malaysia & Equals 1 if the host country is Malaysia & 0.0202 \\
\hline$n z$ & Equals 1 if the host country is New Zealand & 0.0605 \\
\hline portugal & Equals 1 if the host country is Portugal & 0.0121 \\
\hline spain & Equals 1 if the host country is Spain & 0.1290 \\
\hline$u k$ & Equals 1 if the host country is United Kingdom & 0.0565 \\
\hline us & Equals 1 if the host country is United States & 0.3871 \\
\hline us/canada & Equals 1 if the host country is United States or Canada & 0.0081 \\
\hline world & Equals 1 if the estimate was obtained with global data & 0.0403 \\
\hline countrydata & Equals 1 if country-level data are used (vis-a-vis regional or state-level data) & 0.7460 \\
\hline allgoods & Equals 1 if the elasticity is estimated for all goods combined & 0.6371 \\
\hline diffgoods & Equals 1 if the elasticity is estimated for differentiated goods & 0.1613 \\
\hline homgoods & Equals 1 if the elasticity is estimated for homogeneous goods & 0.2016 \\
\hline Idctrade & Equals 1 if the elasticity is estimated for trade between LDC countries only & 0.1169 \\
\hline lagdepvar & Equals 1 if the lagged dependent variable is included in the specification & 0.2742 \\
\hline miginteract & Equals 1 if the migration variable is interacted with other variables & 0.4556 \\
\hline incomepc & Equals 1 if a measure of per capita GDP or income is included & 0.6210 \\
\hline scale & Equals 1 if GDP or population is included & 0.8911 \\
\hline distance & Equals 1 if distance is included in the specification & 0.9274 \\
\hline geography & $\begin{array}{l}\text { Equals } 1 \text { if a variable for adjacency, landlocked, or remoteness is included in the } \\
\text { specification }\end{array}$ & 0.6331 \\
\hline cultnlang & $\begin{array}{l}\text { Equals } 1 \text { if a cultural similarity variable (including common language) is included } \\
\text { in the specification }\end{array}$ & 0.5282 \\
\hline tradeagree & $\begin{array}{l}\text { Equals } 1 \text { if a variable indicating presence of a trade agreement is included in the } \\
\text { specification }\end{array}$ & 0.5565 \\
\hline migskills & Equals 1 if migrant skill composition is accounted in the specification & 0.0444 \\
\hline colonial & $\begin{array}{l}\text { Equals } 1 \text { if a variable indicating presence of colonial ties is included in the } \\
\text { specification }\end{array}$ & 0.0806 \\
\hline pnxtrade & $\begin{array}{l}\text { Equals } 1 \text { if exchange rate (or a measure of relative prices) is included in the } \\
\text { specification }\end{array}$ & 0.4637 \\
\hline homefe & $\begin{array}{l}\text { Equals } 1 \text { if fixed effects for migrant home countries are included in the } \\
\text { specification }\end{array}$ & 0.2621 \\
\hline migdur & $\begin{array}{l}\text { Equals } 1 \text { if a variable that measures the duration of migrants' stay is included in } \\
\text { the specification }\end{array}$ & 0.1089 \\
\hline
\end{tabular}


Table 3: Estimated elasticities by host country

\begin{tabular}{lcccccccc}
\hline & \multicolumn{4}{c}{ Exports } & \multicolumn{5}{c}{ Imports } \\
Country & nr obs & mean & $\min$ & $\max$ & nr obs & mean & min & max \\
Australia & 15 & 0.43 & 0.24 & 0.65 & 15 & 0.21 & -0.05 & 0.44 \\
Bolivia & 1 & 0.08 & 0.08 & 0.08 & 1 & 0.09 & 0.09 & 0.09 \\
Canada & 10 & 0.09 & -0.07 & 0.27 & 10 & 0.26 & 0.08 & 0.41 \\
Denmark & 28 & 0.16 & 0.05 & 0.57 & 28 & 0.13 & 0.04 & 0.34 \\
EU & 8 & 0.27 & 0.02 & 0.65 & 2 & 0.14 & 0.13 & 0.14 \\
Germany & 5 & 0.13 & 0.11 & 0.15 & 1 & 0.01 & 0.01 & 0.01 \\
Greece & 2 & 0.13 & 0.05 & 0.20 & 2 & -0.03 & -0.04 & -0.04 \\
Italy & 2 & 0.05 & 0.01 & 0.08 & 2 & -0.03 & -0.09 & 0.04 \\
Malaysia & 5 & 0.11 & 0.00 & 0.33 & 5 & 0.15 & 0.00 & 0.40 \\
New Zealand & 15 & 0.07 & -0.02 & 0.14 & 15 & 0.19 & -0.04 & 0.49 \\
Portugal & 3 & 0.31 & 0.05 & 0.60 & 3 & 0.35 & 0.23 & 0.56 \\
Spain & 32 & 0.22 & 0.02 & 0.47 & 23 & 0.17 & -0.05 & 0.36 \\
UK & 14 & 0.05 & -0.03 & 0.16 & 10 & 0.05 & -0.01 & 0.23 \\
US & 90 & 0.16 & -0.14 & 0.57 & 50 & 0.19 & -0.18 & 0.47 \\
US/Canada & 2 & -0.03 & -0.11 & 0.06 & 2 & 0.33 & 0.32 & 0.34 \\
World & 1 & 0.37 & 0.37 & 0.37 & 9 & 0.13 & 0.05 & 0.28 \\
Total & $\mathbf{2 3 3}$ & $\mathbf{0 . 1 7}$ & -0.11 & 0.65 & $\mathbf{1 7 8}$ & $\mathbf{0 . 1 7}$ & -0.18 & 0.56 \\
\hline
\end{tabular}

Table 4: Weighted mean effect sizes by host country

\begin{tabular}{lcccccc}
\hline & \multicolumn{3}{c}{ Exports } & \multicolumn{3}{c}{ Imports } \\
Country & nr obs & FE & RE & nr obs & FE & RE \\
Australia & 15 & 0.44 & 0.44 & 15 & 0.15 & 0.20 \\
Bolivia & 1 & 0.08 & 0.08 & 1 & 0.09 & 0.09 \\
Canada & 10 & 0.06 & 0.09 & 10 & 0.19 & 0.25 \\
Denmark & 28 & 0.12 & 0.15 & 28 & 0.12 & 0.13 \\
EU & 8 & 0.15 & 0.27 & 2 & 0.14 & 0.14 \\
Germany & 5 & 0.13 & 0.13 & 1 & 0.01 & 0.01 \\
Greece & 2 & 0.09 & 0.12 & 2 & -0.03 & -0.03 \\
Italy & 2 & 0.04 & 0.04 & 2 & -0.02 & -0.03 \\
Malaysia & 5 & 0.02 & 0.04 & 5 & 0.02 & 0.05 \\
New Zealand & 15 & 0.06 & 0.07 & 15 & 0.09 & 0.19 \\
Portugal & 3 & 0.13 & 0.30 & 3 & 0.42 & 0.37 \\
Spain & 32 & 0.17 & 0.22 & 23 & 0.06 & 0.17 \\
UK & 14 & 0.04 & 0.05 & 10 & 0.05 & 0.06 \\
US & 90 & 0.09 & 0.15 & 50 & 0.16 & 0.19 \\
US/Canada & 2 & -0.03 & -0.03 & 2 & 0.33 & 0.33 \\
World & 1 & 0.37 & 0.37 & 9 & 0.11 & 0.13 \\
Total & $\mathbf{2 3 3}$ & $\mathbf{0 . 1 0}$ & $\mathbf{0 . 1 7}$ & $\mathbf{1 7 8}$ & $\mathbf{0 . 1 0}$ & $\mathbf{0 . 1 6}$ \\
\hline
\end{tabular}


Table 5: Unweighted and weighted mean elasticities by estimation method

\begin{tabular}{lcccccccc}
\hline & \multicolumn{4}{c}{ Exports } & \multicolumn{4}{c}{ Imports } \\
Method & Freq. & Mean & FE & RE & Freq. & Mean & FE & RE \\
Heckman & 10 & 0.10 & 0.10 & 0.10 & 10 & 0.28 & 0.23 & 0.27 \\
IV/3SLS/GMM/FGLS & 20 & 0.35 & 0.16 & 0.35 & 17 & 0.21 & 0.16 & 0.21 \\
OLS & 110 & 0.16 & 0.12 & 0.16 & 84 & 0.15 & 0.07 & 0.14 \\
Pseudo Poisson & 1 & 0.11 & 0.11 & 0.11 & 3 & 0.07 & 0.08 & 0.07 \\
Tobit & 85 & 0.14 & 0.08 & 0.14 & 61 & 0.17 & 0.14 & 0.17 \\
Other & 7 & 0.23 & 0.21 & 0.23 & 3 & 0.30 & 0.32 & 0.32 \\
Total & $\mathbf{2 3 3}$ & $\mathbf{0 . 1 0}$ & $\mathbf{0 . 1 0}$ & $\mathbf{0 . 1 7}$ & $\mathbf{1 7 8}$ & $\mathbf{0 . 1 0}$ & $\mathbf{0 . 1 0}$ & $\mathbf{0 . 1 6}$ \\
\hline
\end{tabular}

Table 6: Unweighted and weighted mean elasticities by publication type

\begin{tabular}{lcccccccc}
\hline & \multicolumn{4}{c}{ Exports } & \multicolumn{4}{c}{ Imports } \\
Outlet & Freq. & Mean & FE & RE & Freq. & Mean & FE & RE \\
Journal & 165 & 0.17 & 0.09 & 0.16 & 133 & 0.16 & 0.10 & 0.16 \\
Unpublished & 68 & 0.18 & 0.13 & 0.18 & 45 & 0.18 & 0.09 & 0.18 \\
Total & $\mathbf{2 3 3}$ & $\mathbf{0 . 1 0}$ & $\mathbf{0 . 1 0}$ & $\mathbf{0 . 1 7}$ & $\mathbf{1 7 8}$ & $\mathbf{0 . 1 0}$ & $\mathbf{0 . 1 0}$ & $\mathbf{0 . 1 6}$ \\
\hline
\end{tabular}


Table 7: OLS and fixed effects meta-regression models

\begin{tabular}{|c|c|c|c|c|}
\hline VARIABLES & $\begin{array}{c}(1) \\
\text { exports }\end{array}$ & $\begin{array}{c}(2) \\
\text { imports }\end{array}$ & $\begin{array}{c}\text { (3) } \\
\text { exports }\end{array}$ & $\begin{array}{c}(4) \\
\text { imports }\end{array}$ \\
\hline \multirow[t]{2}{*}{ seb } & $0.911^{* *}$ & 0.741 & $1.745^{\star *}$ & $1.899^{* *}$ \\
\hline & (0.409) & (0.465) & $(0.780)$ & (0.709) \\
\hline \multirow[t]{2}{*}{ cross } & 0.0409 & $0.693^{* * *}$ & -0.0187 & $0.712^{* * *}$ \\
\hline & $(0.0455)$ & $(0.241)$ & $(0.0397)$ & $(0.0621)$ \\
\hline \multirow[t]{2}{*}{ before 2000} & 0.0517 & 0.0829 & $0.0662^{\star *}$ & $0.119^{\star \star}$ \\
\hline & $(0.0380)$ & $(0.0748)$ & $(0.0319)$ & $(0.0443)$ \\
\hline \multirow[t]{2}{*}{ heckman } & -0.0499 & 0.206 & 0.0130 & $0.223^{* * *}$ \\
\hline & $(0.0724)$ & (0.133) & $(0.0883)$ & $(0.0606)$ \\
\hline \multirow[t]{2}{*}{ iv } & -0.0744 & 0.0865 & $-0.0900^{* \star *}$ & $0.122^{*}$ \\
\hline & $(0.0682)$ & $(0.110)$ & $(0.0277)$ & $(0.0618)$ \\
\hline \multirow[t]{2}{*}{ other } & $0.203^{\star * \star}$ & 0.256 & 0.0530 & 0.0290 \\
\hline & $(0.0765)$ & $(0.206)$ & $(0.0334)$ & $(0.115)$ \\
\hline \multirow[t]{2}{*}{ poisson } & -0.0611 & -0.0227 & $-0.0550^{\star \star *}$ & -0.00369 \\
\hline & $(0.120)$ & (0.0889) & $(0.0149)$ & $(0.0139)$ \\
\hline \multirow[t]{2}{*}{ tobit } & $0.0976^{\star \star *}$ & 0.0598 & 0.0151 & 0.0331 \\
\hline & $(0.0373)$ & $(0.0564)$ & $(0.0381)$ & $(0.0454)$ \\
\hline \multirow[t]{2}{*}{ australia } & $0.287^{\star *}$ & 0.235 & $0.264^{\star * *}$ & 0.0519 \\
\hline & $(0.143)$ & $(0.312)$ & $(0.0567)$ & $(0.169)$ \\
\hline \multirow[t]{2}{*}{ bolivia } & -0.302 & 0.246 & $-0.222^{\star *}$ & 0.194 \\
\hline & $(0.211)$ & $(0.310)$ & $(0.0844)$ & $(0.131)$ \\
\hline \multirow[t]{2}{*}{ canada } & $-0.416^{* *}$ & 0.346 & $-0.320^{* * *}$ & $0.230^{* *}$ \\
\hline & $(0.164)$ & $(0.277)$ & $(0.0654)$ & $(0.105)$ \\
\hline \multirow[t]{2}{*}{ denmark } & -0.233 & $0.496^{*}$ & $-0.179^{\star *}$ & $0.404^{\star * *}$ \\
\hline & $(0.164)$ & $(0.287)$ & $(0.0712)$ & $(0.111)$ \\
\hline \multirow[t]{2}{*}{$e u$} & -0.198 & 0.273 & $-0.200^{* * *}$ & 0.0741 \\
\hline & $(0.143)$ & $(0.258)$ & $(0.0742)$ & $(0.117)$ \\
\hline \multirow[t]{2}{*}{ germany } & $-0.295^{*}$ & & $-0.297^{* * *}$ & \\
\hline & $(0.173)$ & & $(0.0880)$ & \\
\hline \multirow{2}{*}{ greece } & $-0.417^{\star *}$ & 0.00392 & $-0.386^{\star * *}$ & -0.0744 \\
\hline & $(0.166)$ & $(0.244)$ & $(0.0778)$ & $(0.0868)$ \\
\hline \multirow[t]{2}{*}{ italy } & $-0.400^{* *}$ & 0.000270 & $-0.316^{* * *}$ & -0.0519 \\
\hline & $(0.160)$ & $(0.267)$ & $(0.0945)$ & $(0.117)$ \\
\hline \multirow{2}{*}{ malaysia } & $-0.378^{* *}$ & 0.279 & $-0.414^{\star * *}$ & $0.211^{* *}$ \\
\hline & $(0.171)$ & (0.183) & $(0.0945)$ & $(0.0849)$ \\
\hline \multirow[t]{2}{*}{$n z$} & $-0.292^{*}$ & 0.149 & $-0.246^{\star \star *}$ & 0.0718 \\
\hline & $(0.153)$ & (0.282) & $(0.0913)$ & $(0.118)$ \\
\hline \multirow[t]{2}{*}{ portugal } & -0.124 & $0.420^{*}$ & $-0.131^{*}$ & $0.387^{* *}$ \\
\hline & $(0.143)$ & $(0.248)$ & $(0.0744)$ & $(0.171)$ \\
\hline \multirow[t]{2}{*}{ spain } & -0.257 & $0.556^{*}$ & -0.0852 & $0.528^{* * *}$ \\
\hline & $(0.162)$ & $(0.288)$ & $(0.0789)$ & $(0.110)$ \\
\hline \multirow[t]{2}{*}{$u k$} & $-0.384^{\star \star \star}$ & 0.187 & $-0.225^{\star \star \star}$ & $0.167^{*}$ \\
\hline & $(0.143)$ & $(0.230)$ & $(0.0786)$ & $(0.0948)$ \\
\hline \multirow[t]{2}{*}{ us } & $-0.287^{*}$ & 0.0851 & $-0.154^{\star \star}$ & -0.0190 \\
\hline & $(0.149)$ & $(0.266)$ & $(0.0709)$ & $(0.147)$ \\
\hline us/canada & $-0.530^{\star * *}$ & -0.329 & $-0.524^{\star \star \star}$ & $-0.374^{\star \star \star}$ \\
\hline & $(0.192)$ & (0.224) & $(0.0897)$ & (0.0859) \\
\hline countrydata & 0.0476 & -0.00989 & 0.0117 & 0.00186 \\
\hline & $(0.0402)$ & $(0.125)$ & $(0.0295)$ & $(0.0720)$ \\
\hline
\end{tabular}


Table 7: OLS and fixed effects meta-regression models - continued

\begin{tabular}{|c|c|c|c|c|}
\hline VARIABLES & $\begin{array}{c}(1) \\
\text { exports }\end{array}$ & $\begin{array}{c}(2) \\
\text { imports }\end{array}$ & $\begin{array}{c}\text { (3) } \\
\text { exports }\end{array}$ & $\begin{array}{c}\text { (4) } \\
\text { imports }\end{array}$ \\
\hline diffgoods & $\begin{array}{l}-0.0455 \\
(0.0277)\end{array}$ & $\begin{array}{l}0.00862 \\
(0.0328)\end{array}$ & $\begin{array}{l}-0.0190 \\
(0.0263)\end{array}$ & $\begin{array}{l}-0.0124 \\
(0.0339)\end{array}$ \\
\hline homgoods & $\begin{array}{l}-0.121^{* * *} \\
(0.0316)\end{array}$ & $\begin{array}{l}-0.125^{\star * *} \\
(0.0338)\end{array}$ & $\begin{array}{l}-0.0584^{\star *} \\
(0.0247)\end{array}$ & $\begin{array}{l}-0.104^{\star \star *} \\
(0.0182)\end{array}$ \\
\hline Idctrade & $\begin{array}{l}0.0587^{* *} \\
(0.0267)\end{array}$ & $\begin{array}{c}0.0504 \\
(0.0328)\end{array}$ & $\begin{array}{l}-0.0188 \\
(0.0444)\end{array}$ & $\begin{array}{c}-0.000239 \\
(0.0538)\end{array}$ \\
\hline lagdepvar & $\begin{array}{c}-0.0670^{* *} \\
(0.0335)\end{array}$ & $\begin{array}{l}-0.126^{\star *} \\
(0.0513)\end{array}$ & $\begin{array}{l}-0.0105 \\
(0.0164)\end{array}$ & $\begin{array}{l}-0.0825 \\
(0.0563)\end{array}$ \\
\hline miginteract & $\begin{array}{c}0.0172 \\
(0.0275)\end{array}$ & $\begin{array}{l}0.00436 \\
(0.0445)\end{array}$ & $\begin{array}{c}0.0105 \\
(0.00994)\end{array}$ & $\begin{array}{c}0.0119 \\
(0.0403)\end{array}$ \\
\hline incomepc & $\begin{array}{l}-0.0752 \\
(0.0785)\end{array}$ & $\begin{array}{c}0.229 \\
(0.146)\end{array}$ & $\begin{array}{l}-0.0230 \\
(0.0364)\end{array}$ & $\begin{array}{l}0.235^{\star * *} \\
(0.0461)\end{array}$ \\
\hline scale & $\begin{array}{c}0.0648 \\
(0.0790)\end{array}$ & $\begin{array}{l}0.0636 \\
(0.157)\end{array}$ & $\begin{array}{l}-0.0144 \\
(0.0584)\end{array}$ & $\begin{array}{c}0.124 \\
(0.0798)\end{array}$ \\
\hline distance & $\begin{array}{l}0.105^{\star *} \\
(0.0438)\end{array}$ & $\begin{array}{l}-0.0332 \\
(0.0795)\end{array}$ & $\begin{array}{l}0.141^{* * *} \\
(0.0314)\end{array}$ & $\begin{array}{l}0.00886 \\
(0.0370)\end{array}$ \\
\hline geography & $\begin{array}{l}-0.0390 \\
(0.0294)\end{array}$ & $\begin{array}{l}-0.0471 \\
(0.0455)\end{array}$ & $\begin{array}{l}-0.0390^{*} \\
(0.0226)\end{array}$ & $\begin{array}{c}-0.0508^{* * *} \\
(0.0146)\end{array}$ \\
\hline cultnlang & $\begin{array}{l}-0.0408 \\
(0.0300)\end{array}$ & $\begin{array}{c}0.0131 \\
(0.0416)\end{array}$ & $\begin{array}{l}-0.0549 \\
(0.0579)\end{array}$ & $\begin{array}{c}-0.00508 \\
(0.0144)\end{array}$ \\
\hline tradeagree & $\begin{array}{l}-0.0282 \\
(0.0300)\end{array}$ & $\begin{array}{l}-0.0698 \\
(0.0458)\end{array}$ & $\begin{array}{l}-0.00597 \\
(0.0267)\end{array}$ & $\begin{array}{c}-0.0592^{* * *} \\
(0.0215)\end{array}$ \\
\hline migskills & $\begin{array}{l}-0.0384 \\
(0.0482)\end{array}$ & $\begin{array}{l}-0.0641 \\
(0.0623)\end{array}$ & $\begin{array}{l}-0.0345 \\
(0.0431)\end{array}$ & $\begin{array}{l}-0.0853 \\
(0.0646)\end{array}$ \\
\hline colonial & $\begin{array}{l}-0.0649 \\
(0.0512)\end{array}$ & $\begin{array}{l}-0.0542 \\
(0.0666)\end{array}$ & $\begin{array}{l}-0.109^{* *} \\
(0.0417)\end{array}$ & $\begin{array}{l}-0.0694 \\
(0.0530)\end{array}$ \\
\hline pnxtrate & $\begin{array}{l}-0.119^{\star *} \\
(0.0538)\end{array}$ & $\begin{array}{c}0.156 \\
(0.112)\end{array}$ & $\begin{array}{l}-0.0642 \\
(0.0405)\end{array}$ & $\begin{array}{l}0.180^{\star \star *} \\
(0.0265)\end{array}$ \\
\hline homefe & $\begin{array}{l}0.00143 \\
(0.0258)\end{array}$ & $\begin{array}{l}-0.0393 \\
(0.0373)\end{array}$ & $\begin{array}{l}-0.00139 \\
(0.0201)\end{array}$ & $\begin{array}{r}-0.00752 \\
(0.0163)\end{array}$ \\
\hline migdur & $\begin{array}{l}-0.0679 \\
(0.0615)\end{array}$ & $\begin{array}{c}0.125 \\
(0.152)\end{array}$ & $\begin{array}{l}-0.0849 \\
(0.0543)\end{array}$ & $\begin{array}{l}0.221^{\star \star *} \\
(0.0500)\end{array}$ \\
\hline Constant (average effect) & $\begin{array}{l}0.170^{* * \star} \\
(0.007)\end{array}$ & $\begin{array}{c}0.169^{\star * *} \\
(0.009)\end{array}$ & $\begin{array}{c}0.176^{\star * \star} \\
(0.010)\end{array}$ & $\begin{array}{l}0.176^{* * *} \\
(0.009)\end{array}$ \\
\hline $\begin{array}{l}\text { Observations } \\
\text { R-squared }\end{array}$ & $\begin{array}{c}233 \\
0.554\end{array}$ & $\begin{array}{c}178 \\
0.440\end{array}$ & $\begin{array}{c}233 \\
0.644\end{array}$ & $\begin{array}{c}178 \\
0.688\end{array}$ \\
\hline
\end{tabular}

Notes: Standard errors in parentheses. ${ }^{* * *} p<0.01,{ }^{* *} p<0.05, * p<0.1$

The columns report regression coefficients of linear regression models explaining the immigration elasticity of exports (columns (1) and (3)) and imports (columns (2) and (4)). Columns (1) and (2) display benchmark OLS coefficients. Columns (3) and (4) report coefficients of the fixed effects model, estimated by WLS (with weights equal to the reciprocal of the squared standard errors of the effect sizes); with the standard errors in parenthesis adjusted for clustering by publications. There were 44 publication clusters in column (3) and 32 in column (4). The reference dummies are ols for methodologies, world for geographical area, and allgoods for product differentiation. The dummy variable for Germany was omitted in the imports equations due to perfect collinearity. 
Table 8: Random effects and publication-bias corrected meta-regression models

\begin{tabular}{|c|c|c|c|c|}
\hline VARIABLES & $\begin{array}{c}\text { (1) } \\
\text { exports }\end{array}$ & $\begin{array}{c}(2) \\
\text { imports }\end{array}$ & $\begin{array}{c}(3) \\
\text { exports }\end{array}$ & $\begin{array}{c}\text { (4) } \\
\text { imports }\end{array}$ \\
\hline \multirow[t]{2}{*}{ cross } & 0.0410 & $0.660^{\star * *}$ & 0.0399 & $0.679^{* * *}$ \\
\hline & $(0.0443)$ & $(0.217)$ & $(0.0397)$ & $(0.174)$ \\
\hline \multirow[t]{2}{*}{ before 2000} & $0.0714^{*}$ & 0.0909 & $0.0723^{* *}$ & $0.112^{*}$ \\
\hline & $(0.0369)$ & $(0.0723)$ & $(0.0329)$ & $(0.0599)$ \\
\hline \multirow[t]{2}{*}{ heckman } & -0.0307 & 0.197 & -0.0280 & $0.220^{* *}$ \\
\hline & $(0.0705)$ & $(0.120)$ & $(0.0621)$ & $(0.101)$ \\
\hline \multirow[t]{2}{*}{ iv } & -0.0831 & 0.170 & -0.0816 & 0.159 \\
\hline & $(0.0637)$ & $(0.108)$ & $(0.0559)$ & $(0.0997)$ \\
\hline \multirow[t]{2}{*}{ other } & $0.173^{* *}$ & $0.341^{*}$ & $0.171^{* * *}$ & 0.278 \\
\hline & $(0.0736)$ & $(0.206)$ & $(0.0655)$ & $(0.177)$ \\
\hline \multirow[t]{2}{*}{ poisson } & -0.0758 & -0.0323 & -0.0732 & -0.0227 \\
\hline & $(0.109)$ & $(0.0755)$ & $(0.0952)$ & $(0.0613)$ \\
\hline \multirow[t]{2}{*}{ tobit } & $0.0725^{\star *}$ & 0.0684 & $0.0740^{* *}$ & 0.0665 \\
\hline & $(0.0349)$ & $(0.0524)$ & $(0.0310)$ & $(0.0454)$ \\
\hline \multirow[t]{2}{*}{ australia } & 0.245 & 0.0529 & 0.248 & 0.107 \\
\hline & (0.164) & $(0.291)$ & (0.154) & $(0.239)$ \\
\hline \multirow[t]{2}{*}{ bolivia } & $-0.359^{\star}$ & 0.166 & $-0.353^{*}$ & 0.205 \\
\hline & $(0.216)$ & $(0.286)$ & $(0.197)$ & $(0.227)$ \\
\hline \multirow[t]{2}{*}{ canada } & $-0.467^{* *}$ & 0.236 & $-0.465^{\star * *}$ & 0.266 \\
\hline & $(0.180)$ & $(0.255)$ & $(0.166)$ & (0.204) \\
\hline \multirow[t]{2}{*}{ denmark } & -0.283 & 0.396 & $-0.280^{*}$ & $0.434^{* *}$ \\
\hline & (0.179) & $(0.268)$ & $(0.166)$ & $(0.215)$ \\
\hline \multirow[t]{2}{*}{$e u$} & $-0.275^{\star}$ & 0.272 & $-0.272^{*}$ & 0.276 \\
\hline & $(0.160)$ & $(0.262)$ & $(0.150)$ & $(0.208)$ \\
\hline \multirow[t]{2}{*}{ germany } & $-0.372^{* *}$ & & $-0.379^{* *}$ & \\
\hline & $(0.187)$ & & $(0.173)$ & \\
\hline \multirow[t]{2}{*}{ greece } & $-0.502^{* * *}$ & -0.0718 & $-0.506^{* * *}$ & -0.0525 \\
\hline & $(0.179)$ & $(0.231)$ & $(0.167)$ & (0.182) \\
\hline \multirow[t]{2}{*}{ italy } & $-0.449^{\star *}$ & -0.0674 & $-0.446^{\star * *}$ & -0.00653 \\
\hline & $(0.176)$ & $(0.256)$ & $(0.163)$ & $(0.206)$ \\
\hline \multirow[t]{2}{*}{ malaysia } & $-0.445^{\star *}$ & 0.248 & $-0.460^{\star * *}$ & $0.238^{*}$ \\
\hline & $(0.191)$ & $(0.178)$ & $(0.175)$ & $(0.133)$ \\
\hline \multirow[t]{2}{*}{$n z$} & $-0.377^{\star \star}$ & 0.0528 & $-0.374^{\star *}$ & 0.0879 \\
\hline & $(0.169)$ & $(0.264)$ & $(0.157)$ & $(0.212)$ \\
\hline \multirow[t]{2}{*}{ portugal } & -0.172 & $0.410^{*}$ & -0.173 & $0.451^{\star *}$ \\
\hline & $(0.164)$ & $(0.247)$ & (0.154) & $(0.200)$ \\
\hline \multirow[t]{2}{*}{ spain } & $-0.300^{*}$ & $0.474^{*}$ & $-0.287^{*}$ & $0.516^{\star *}$ \\
\hline & $(0.174)$ & $(0.267)$ & $(0.162)$ & $(0.214)$ \\
\hline \multirow[t]{2}{*}{$u k$} & $-0.430^{\star * *}$ & 0.128 & $-0.427^{\star \star \star}$ & 0.156 \\
\hline & $(0.162)$ & $(0.221)$ & $(0.152)$ & $(0.174)$ \\
\hline \multirow[t]{2}{*}{ us } & $-0.324^{\star}$ & 0.0106 & $-0.324^{* \star}$ & 0.0473 \\
\hline & $(0.166)$ & $(0.258)$ & $(0.155)$ & $(0.208)$ \\
\hline \multirow[t]{2}{*}{ us/canada } & $-0.587^{\star \star \star}$ & $-0.382^{*}$ & $-0.589^{\star \star *}$ & $-0.368^{* \star}$ \\
\hline & $(0.207)$ & $(0.205)$ & $(0.188)$ & $(0.175)$ \\
\hline \multirow[t]{2}{*}{ countrydata } & 0.0596 & -0.0859 & 0.0565 & -0.0485 \\
\hline & $(0.0391)$ & $(0.114)$ & $(0.0348)$ & (0.0992) \\
\hline
\end{tabular}


Table 8: Random effects and publication-bias corrected meta-regression models - continued

\begin{tabular}{|c|c|c|c|c|}
\hline VARIABLES & $\begin{array}{c}(1) \\
\text { exports }\end{array}$ & $\begin{array}{c}(2) \\
\text { imports }\end{array}$ & $\begin{array}{c}(3) \\
\text { exports }\end{array}$ & $\begin{array}{c}(4) \\
\text { imports }\end{array}$ \\
\hline \multirow[t]{2}{*}{ diffgoods } & -0.0405 & 0.0141 & $-0.0408^{*}$ & 0.0141 \\
\hline & $(0.0265)$ & $(0.0298)$ & $(0.0236)$ & $(0.0260)$ \\
\hline \multirow{2}{*}{ homgoods } & $-0.0887^{* * *}$ & $-0.100^{* * *}$ & $-0.0914^{* * *}$ & $-0.110^{\star * *}$ \\
\hline & $(0.0297)$ & (0.0302) & $(0.0269)$ & $(0.0258)$ \\
\hline \multirow{2}{*}{ Idctrade } & 0.0375 & 0.0310 & 0.0367 & 0.0298 \\
\hline & $(0.0261)$ & $(0.0314)$ & $(0.0234)$ & (0.0265) \\
\hline \multirow[t]{2}{*}{ lagdepvar } & $-0.0618^{*}$ & $-0.138^{\star * *}$ & $-0.0590^{* *}$ & $-0.117^{\star \star *}$ \\
\hline & (0.0322) & $(0.0471)$ & $(0.0282)$ & $(0.0381)$ \\
\hline \multirow[t]{2}{*}{ miginteract } & 0.0167 & 0.0189 & 0.0160 & 0.0126 \\
\hline & $(0.0267)$ & $(0.0404)$ & $(0.0238)$ & $(0.0341)$ \\
\hline \multirow[t]{2}{*}{ incomepc } & -0.0613 & $0.223^{*}$ & -0.0549 & $0.223^{* *}$ \\
\hline & (0.0749) & $(0.127)$ & $(0.0653)$ & $(0.108)$ \\
\hline \multirow[t]{2}{*}{ scale } & 0.0503 & 0.116 & 0.0424 & 0.0891 \\
\hline & (0.0782) & $(0.158)$ & (0.0684) & $(0.130)$ \\
\hline \multirow[t]{2}{*}{ distance } & $0.106^{* \star}$ & -0.0184 & $0.112^{\star \star \star}$ & -0.0135 \\
\hline & $(0.0447)$ & $(0.0761)$ & $(0.0395)$ & $(0.0620)$ \\
\hline \multirow[t]{2}{*}{ geography } & $-0.0506^{*}$ & -0.0570 & $-0.0503^{* *}$ & -0.0575 \\
\hline & $(0.0276)$ & $(0.0430)$ & $(0.0244)$ & $(0.0373)$ \\
\hline \multirow[t]{2}{*}{ cultnlang } & -0.0481 & 0.0141 & $-0.0497^{*}$ & 0.00675 \\
\hline & $(0.0297)$ & $(0.0400)$ & $(0.0264)$ & $(0.0346)$ \\
\hline \multirow[t]{2}{*}{ tradeagree } & -0.0215 & $-0.0765^{\star}$ & -0.0211 & $-0.0749^{* *}$ \\
\hline & $(0.0292)$ & $(0.0423)$ & $(0.0260)$ & $(0.0363)$ \\
\hline \multirow[t]{2}{*}{ migskills } & -0.0348 & -0.0639 & -0.0352 & -0.0625 \\
\hline & $(0.0471)$ & $(0.0571)$ & $(0.0417)$ & $(0.0455)$ \\
\hline \multirow[t]{2}{*}{ colonial } & -0.0802 & -0.0574 & $-0.0813^{*}$ & -0.0653 \\
\hline & $(0.0490)$ & $(0.0607)$ & $(0.0435)$ & $(0.0518)$ \\
\hline \multirow[t]{2}{*}{ pnxtrate } & $-0.112^{\star *}$ & $0.168^{*}$ & $-0.111^{\star *}$ & $0.152^{*}$ \\
\hline & $(0.0521)$ & $(0.0987)$ & $(0.0459)$ & $(0.0817)$ \\
\hline \multirow{2}{*}{ homefe } & 0.00115 & -0.0299 & -0.000373 & -0.0275 \\
\hline & $(0.0253)$ & $(0.0347)$ & $(0.0223)$ & $(0.0289)$ \\
\hline \multirow[t]{2}{*}{ migdur } & -0.0700 & 0.137 & -0.0706 & 0.132 \\
\hline & (0.0599) & $(0.139)$ & (0.0530) & $(0.117)$ \\
\hline \multirow{2}{*}{ Constant (average effect) } & $0.168^{* * *}$ & $0.168^{* * *}$ & $0.164^{\star \star \star}$ & $0.150^{* \star *}$ \\
\hline & $(0.007)$ & $(0.009)$ & $(0.007)$ & $(0.009)$ \\
\hline Observations & 233 & 178 & 233 & 178 \\
\hline Adj R-squared & 0.512 & 0.413 & & \\
\hline
\end{tabular}

Notes: Standard errors in parentheses. ${ }^{* * *} p<0.01,{ }^{* *} p<0.05, * p<0.1$

The columns report regression coefficients of maximum likelihood linear models explaining the immigration elasticity of exports (columns (1) and (3)) and imports (columns (2) and (4)). Columns (1) and (2) display coefficients of the random effects regression model estimated by residual (restricted) maximum likelihood (REML) . Columns (3) and (4) report coefficients of the Ashenfelter et al. (1999) publication bias model. The reference dummies are ols for methodologies, world for geographical area, and allgoods for product differentiation. The dummy variable for Germany was omitted in the imports equations for comparison with Table 7. 
Table 9 Summary of publication-bias corrected RE estimates

\begin{tabular}{|c|c|c|c|c|}
\hline \multicolumn{5}{|c|}{ Without accounting for study characteristics } \\
\hline Exports & $\begin{array}{l}\text { Publication bias } \\
\text { assumed }\end{array}$ & SE & $\begin{array}{l}\text { No publication } \\
\text { bias } \\
\text { assumed }\end{array}$ & SE \\
\hline$\widehat{\omega}_{2}$ & $1.305 * * *$ & 0.324 & 1.000 & - \\
\hline$\widehat{\omega}_{3}$ & $0.745 * * *$ & 0.160 & 1.000 & - \\
\hline $\mathrm{RE}$ & $0.162 * * *$ & 0.012 & $0.168 * * *$ & 0.010 \\
\hline$\hat{\tau}_{\alpha}$ & $0.143 * * *$ & 0.007 & $0.142 * * *$ & 0.007 \\
\hline Log-likelihood & 326.42 & & 324.16 & \\
\hline$n$ & 233 & & 233 & \\
\hline \multicolumn{5}{|l|}{ Imports } \\
\hline$\widehat{\omega}_{2}$ & $0.664 * * *$ & 0.197 & 1.000 & - \\
\hline$\widehat{\omega}_{3}$ & $0.417 * * *$ & 0.103 & 1.000 & - \\
\hline $\mathrm{RE}$ & $0.136 * * *$ & 0.012 & $0.164 * * *$ & 0.010 \\
\hline$\hat{\tau}_{\beta}$ & $0.126 * * *$ & 0.007 & $0.127 * * *$ & 0.008 \\
\hline Log-likelihood & 265.46 & & 259.07 & \\
\hline$n$ & 178 & & 178 & \\
\hline \multicolumn{5}{|c|}{ With accounting for study characteristics } \\
\hline Exports & $\begin{array}{l}\text { Publication bias } \\
\text { assumed }\end{array}$ & & $\begin{array}{l}\text { No publication } \\
\text { bias } \\
\text { assumed }\end{array}$ & \\
\hline$\widehat{\omega}_{2}$ & $1.288 * * *$ & 0.330 & 1.000 & - \\
\hline$\widehat{\omega}_{3}$ & $0.702 * * *$ & 0.169 & 1.000 & - \\
\hline $\mathrm{RE}$ & $0.164 * * *$ & 0.007 & $0.168 * * *$ & 0.006 \\
\hline$\hat{\tau}_{\alpha}$ & $0.088 * * *$ & 0.005 & $0.088 * * *$ & 0.005 \\
\hline Log-likelihood & 421.36 & & 418.83 & \\
\hline$n$ & 233 & & 233 & \\
\hline \multicolumn{5}{|l|}{ Imports } \\
\hline$\widehat{\omega}_{2}$ & $0.625 * * *$ & 0.189 & 1.000 & - \\
\hline$\widehat{\omega}_{3}$ & $0.401 * * *$ & 0.110 & 1.000 & - \\
\hline $\mathrm{RE}$ & $0.150 * * *$ & 0.009 & $0.168 * * *$ & 0.008 \\
\hline$\hat{\tau}_{\beta}$ & $0.081 * * *$ & 0.006 & $0.082 * * *$ & 0.005 \\
\hline Log-likelihood & 322.29 & & 316.59 & \\
\hline$n$ & 178 & & 178 & \\
\hline
\end{tabular}

* significant at $10 \%$ level; ${ }^{* *}$ significant at $5 \%$ level; *** significant at $1 \%$ level

Notes: These estimates have been obtained with the maximum likelihood procedure described in Hedges (1992), Ashenfelter et al. (1999) and Nijkamp and Poot (2005). The coefficient of the study characteristics that are included in the models of the lower half of the table can be found in columns (3) and (4) of Table 8. 
Figure 1: Quantile plots of the migration elasticities of exports and imports
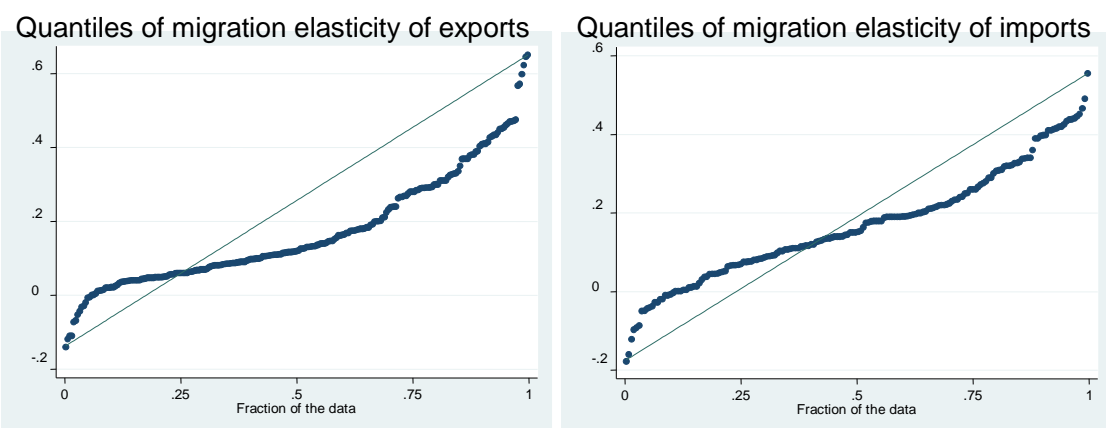

Figure 2: Scatter plot of the migration elasticity of imports and exports when estimated jointly

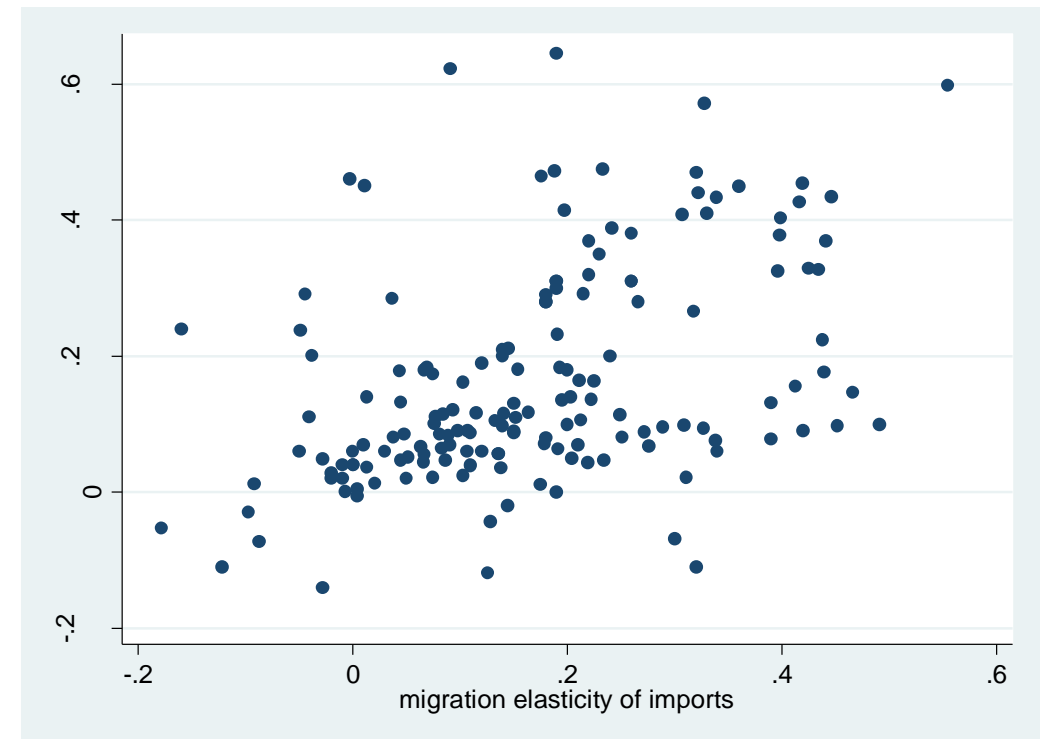


Figure 3: Simple funnel plots of immigration elasticities of exports and imports
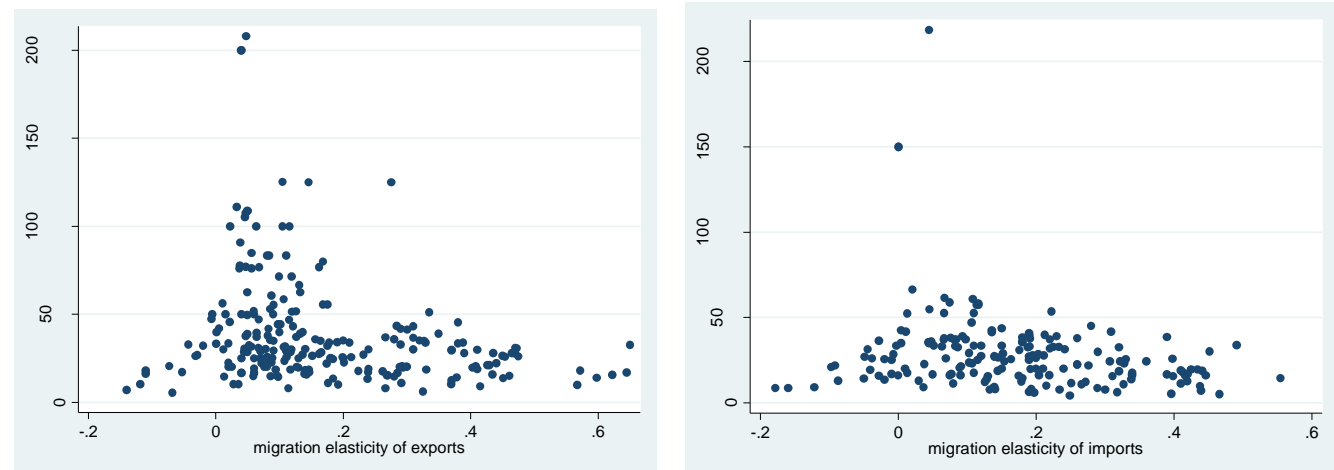